\title{
Nitrogen fluxes through the lower estuary of the river Great Ouse, England: the role of the bottom sediments
}

\author{
M. Trimmer ${ }^{1}$, D. B. Nedwell ${ }^{1, *}$, D. B. Sivyer ${ }^{2}$, S. J. Malcolm ${ }^{2}$ \\ ${ }^{1}$ Department of Biological Sciences, University of Essex, Colchester CO4 3SQ, United Kingdom \\ ${ }^{2}$ Centre for Environment Fisheries and Aquaculture Sciences, Pakefield Road, Lowestoft, Suffolk NR33 0HT, United Kingdom
}

\begin{abstract}
Sediment-water nutrient exchange, oxygen uptake, denitrification (acetylene blockage) and pore water nutrient concentration profiles were measured at intertidal sediment (predominantly silt/clays) sites in the lower estuary of the river Great Ouse. England. Sediments were consistent sinks for $\mathrm{NO}_{3}^{-}\left(310 \mu \mathrm{mol} \mathrm{m}{ }^{-2} \mathrm{~h}^{-1}\right.$, mean sites 4 to 9$)$ and $\mathrm{O}_{2}\left(2800 \mu \mathrm{mol} \mathrm{m}^{-2} \mathrm{~h}^{-1}\right.$, mean sites 4 to 7$)$, sources of $\mathrm{NH}_{4}{ }^{+}\left(270 \mu \mathrm{mol} \mathrm{m} \mathrm{m}^{-2} \mathrm{~h}^{-1}\right.$, mean sites 4 to 9) but neutral with respect to $\mathrm{NO}_{2}^{-}$and urea. Oxygen uptake was significantly correlated $(p<0.05)$ with seasonal temperature. Nitrate exchange became saturated at $\mathrm{NO}_{3}^{-}$concentrations $>400 \mu \mathrm{M}$, at a rate of about $400 \mu \mathrm{mol} \mathrm{NO} \mathrm{NO}_{3}^{-} \mathrm{m}^{-2} \mathrm{~h}^{-1}$. Denitrification accounted annually for $46 \%$ of the $\mathrm{NO}_{3}^{-}$exchanged into the sediments and approached asymptotic rates during spring and summer at $\mathrm{NO}_{3}{ }^{-}$concentrations $>400 \mu \mathrm{M}$. Of the total $\mathrm{N}$ flux through the sediments, $\mathrm{NH}_{4}{ }^{+}$ efflux accounted for $51 \%$, whilst $49 \%$ was converted to gases, compared to $>90 \%$ in the upper estuary. Freshwater flushing times were calculated for a defined area of the estuary and ranged from $20.5 \mathrm{~d}$ in June to $3.25 \mathrm{~d}$ in November. Attenuation of the riverine total oxidised nitrogen $\left(\mathrm{NO}_{3}{ }^{-}+\mathrm{NO}_{2}^{-}\right)$load to the estuary ranged from $1 \%$ in the middle of winter to $56 \%$ at the height of summer and annually the sediments denitrified $38.4 \mathrm{Mmol} \mathrm{N}$. Recycling of nitrogen in the sediments, via $\mathrm{NO}_{3}{ }^{-}$ammonification (calculated by difference) and organic ammonification, generated an annual $\mathrm{NH}_{4}^{*}$ efflux of $128 \mathrm{Mmol}$ $\mathrm{N}$, equivalent to $22 \%$ of the primary production $\mathrm{N}$ requirement in the Wash.
\end{abstract}

KEY WORDS: Bottom sediments - Denitrification · Freshwater flushing - Nutrient attenuation

\section{INTRODUCTION}

The ability of estuaries to attenuate and divert riverine nutrient loads (primarily nitrogen and phosphorus) away from coastal seas has been studied increasingly over the past 3 decades (Nedwell 1975, Seitzinger et al. 1980, Billen et al. 1985, Law et al. 1991, Nielsen et al 1995, Nedwell \& Trimmer 1996. Nixon et al. 1996 Ogilvie et al. 1997), with denitrification receiving a great deal of attention. The fractional loss of riverine nutrient loads via either denitrification, primary production or sediment burial, within an estuary, does in part seem to be related to the estuary flushing time or residence time (Balls 1994, Nixon et al. 1996). However, estuarine sediments may also add fixed available

•Addressee for correspondence. E-mail: nedwd@essex.ac.uk
$\mathrm{N}$ (primarily $\mathrm{NH}_{4}{ }^{+}$) to the overlying water via $\mathrm{NO}_{3}{ }^{-}$ ammonification and organic ammonification and are often a substantial source of $\mathrm{N}$ for pelagic primary production (Billen \& Lancelot 1988).

The role of the bottom sediments in the $\mathrm{N}$ budget of the upper estuary of the Great Ouse was reported in Nedwell \& Trimmer (1996). Although $>90 \%$ of the total sedimentary $\mathrm{N}$ flux was to $\mathrm{N}$ gases and the sediments of the upper Great Ouse estuary were removing $\mathrm{NO}_{3}{ }^{-}$ from the water column at a maximal rate throughout the year, the intense denitrification could only attenuate $\sim 1 \%$ of the total oxidised nitrogen (TOxN; nitrate + nitrite) load. Such a small proportionate removal was due to the very high ratio of $\mathrm{N}$ load (in the water) to sediment surface area (areal $\mathrm{N}$ load) in this section of the river ( $455 \mathrm{~mol} \mathrm{~N} \mathrm{~m}^{-2} \mathrm{yr}^{-1}$ ). The influence of the sediments via recycled $\mathrm{N}$ on the $\mathrm{NH}_{4}{ }^{+}$load was also very 


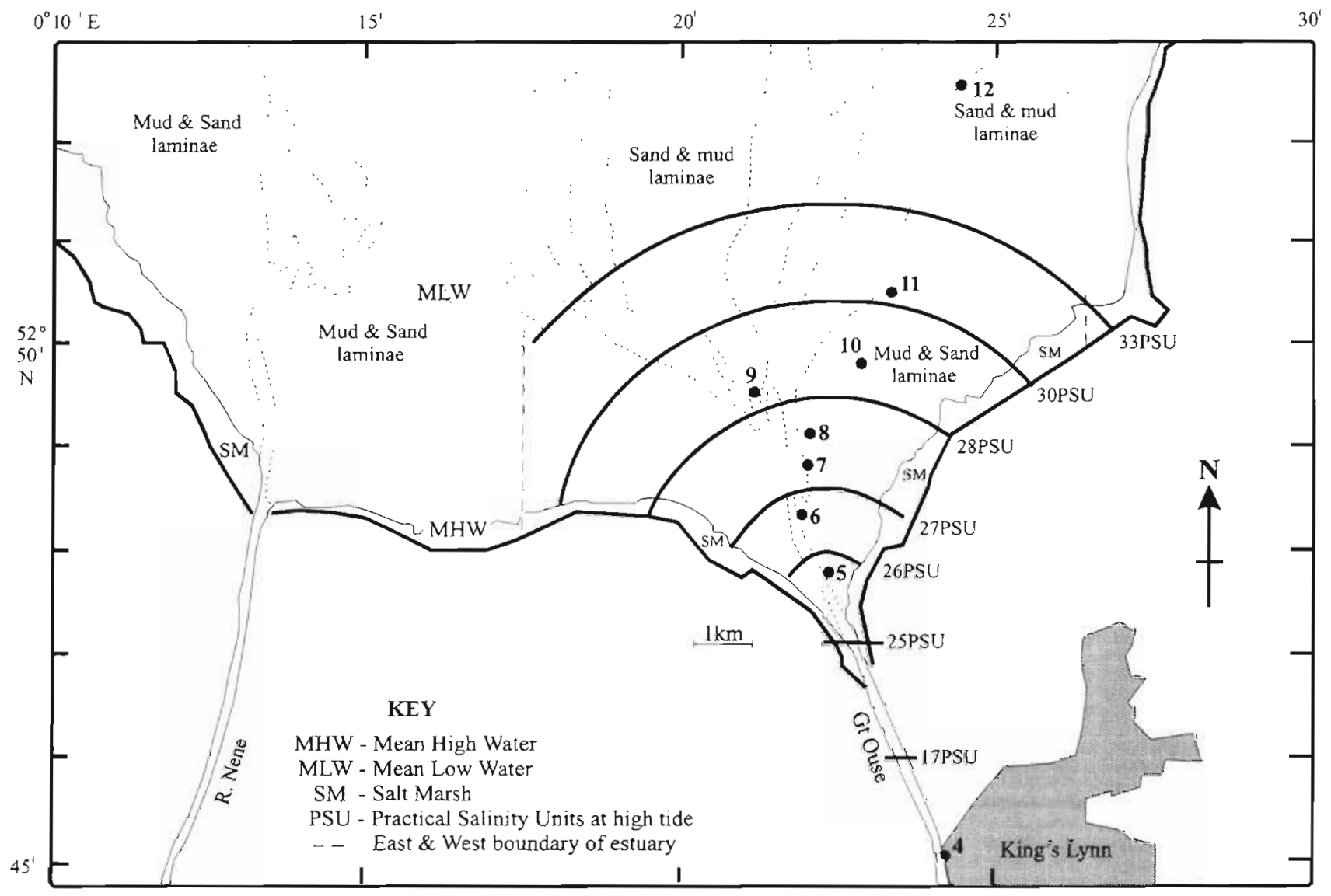

Fig. 1. Map of the lower part of the Great Ouse estuary, east coast UK, showing the positions of the 9 sampling sites and the extent of the intertidal flats of the Wash covered by the Great Ouse estuary at high tide

small. The main aims of the current study were therefore to identify whether sedimentary $\mathrm{N}$ cycling in the much larger areas of intertidal flats at the mouth of the lower Great Ouse, at the edge of the Wash embayment, would have a greater effect on the $N$ load of the Great Ouse compared to that measured in the upper estuary.

\section{MATERIALS AND METHODS}

Sample sites and sediment characteristics. This study examined a stretch of the Great Ouse estuary seaward of that described by Nedwell \& Trimmer (1996). Seaward of King's Lynn (site 4) the estuary widens from approximately 100 to $250 \mathrm{~m}$ at the mouth (site 5), where it then rapidly broadens out over the expansive intertidal flats at the edge of the Wash embayment. Sites 5, 6, 7, 8, 10 and 11 (Fig. 1) were situated on the intertidal flats which were predominantly silt/clays, $65 \%(\mathrm{w} / \mathrm{w})$ of particles $<63 \mu \mathrm{m}$ diameter. Sites 9 and 12 were seaward of the intertidal flats, where the sediments were dominated by fine sands with $85 \%(\mathrm{w} / \mathrm{w})$ of particles 250 to $125 \mu \mathrm{m}$ diameter. Further sediment characteristics for the 9 sites are given in Table 1, measured as described by Nedwell \& Trimmer (1996). Sites 4 to 9 (Fig. 1) were visited regularly between April 1994 and April 1995 at low tide using a small inflatable boat. Sites 10,11 and 12 (Fig. 1) were visited (in turn on consecutive high tides) regularly between July 1990 and June 1994 at high tide using a flat-bottomed boat, grounding, and waiting to dry out at low tide.

Water column nutrients. Water samples $(20 \mathrm{ml})$ were collected from sites 4 to 9 , immediately filtered $(0.2 \mu \mathrm{m}$ Minisart Plus ${ }^{\mathrm{TM}}$, Sartorius UK Ltd), frozen in dry ice and stored at $-20^{\circ} \mathrm{C}$ until analysed. After thawing, samples were analysed for nitrate, nitrite, ammonium and salinity on all occasions, and for urea in July 1994, according to the methods described in Nedwell \& Trimmer (1996).

Pore water nutrient profiles. Duplicate sediment pore water profiles were collected from sites 10, 11 and 12 using an in situ vacuum 'sipper' system on each visit immediately after exposure at low tide (D. B. Sivyer \& S. J. Malcolm unpubl.). Each probe 
Table 1. Average sediment characteristics for the 9 sites investigated. Sites 4 to 9 measured in May $1994 ;$ top $1-2 \mathrm{~cm} \pm \mathrm{SE}, \mathrm{n}=6$. Sites 10, 11 and 12 measured July 1990 to June 1994; top $1 \mathrm{~cm} \pm \mathrm{SE}, \mathrm{n}=13$

\begin{tabular}{|c|c|c|c|c|c|c|c|}
\hline Site & $\begin{array}{l}\text { Particle size } \\
(>50 \% \mathrm{w} / \mathrm{w})\end{array}$ & $\begin{array}{l}\text { Water content } \\
\text { ( } \mathrm{g} \mathrm{H}_{2} \mathrm{O} \mathrm{g}^{-1} \text { sed.) }\end{array}$ & $\begin{array}{l}\text { Specific gravity } \\
\left(\mathrm{g} \mathrm{cm}^{-3} \text { sed.) }\right.\end{array}$ & $\begin{array}{c}\text { Porosity } \\
\left(\mathrm{cm}^{3} \mathrm{H}_{2} \mathrm{O} \mathrm{cm}^{-3} \text { sed. }\right)\end{array}$ & $\begin{array}{l}\text { Organic C } \\
(\% \text { dry wt })\end{array}$ & $\begin{array}{c}\text { Total } N \\
(\% \text { dry wt })\end{array}$ & $\begin{array}{l}\mathrm{C}: \mathrm{N} \text { ratio } \\
\text { (mol:mol) }\end{array}$ \\
\hline 4 & Very fine sands & $0.23 \pm 0.01$ & $1.69 \pm 0.06$ & $0.38 \pm 0.01$ & $0.10 \pm 0.01$ & $0.02 \pm 0.01$ & $5: 1$ \\
\hline 5 & Silt/clays & $0.33 \pm 0.03$ & $1.75 \pm 0.14$ & $0.57 \pm 0.03$ & $0.78 \pm 0.23$ & $0.07 \pm 0.02$ & $13: 1$ \\
\hline 6 & Very fine sands & $0.21 \pm 0.01$ & $1.81 \pm 0.07$ & $0.38 \pm 0.01$ & $0.21 \pm 0.03$ & $0.02 \pm 0.00$ & $17: 1$ \\
\hline 7 & Silt/clays & $0.44 \pm 0.03$ & $1.39 \pm 0.05$ & $0.61 \pm 0.02$ & $2.23 \pm 0.35$ & $0.14 \pm 0.02$ & 19:1 \\
\hline 8 & Silt/clays & $0.26 \pm 0.02$ & $1.73 \pm 0.04$ & $0.45 \pm 0.03$ & $0.44 \pm 0.17$ & $0.03 \pm 0.01$ & $18: 1$ \\
\hline 9 & Fine sands & $0.39 \pm 0.03$ & $1.46 \pm 0.06$ & $0.56 \pm 0.02$ & $0.36 \pm 0.08$ & $0.06 \pm 0.02$ & $8: 1$ \\
\hline 10 & Silt/clays & $0.41 \pm 0.12$ & $1.49 \pm 0.13$ & $0.61 \pm 0.13$ & $1.14 \pm 0.79$ & $0.09 \pm 0.07$ & $15: 1$ \\
\hline 11 & Silt/clays & $0.37 \pm 0.09$ & $1.68 \pm 0.10$ & $0.62 \pm 0.10$ & $1.72 \pm 0.51$ & $0.14 \pm 0.05$ & $14: 1$ \\
\hline 12 & Fine sands & $0.20 \pm 0.05$ & $1.95 \pm 0.08$ & $0.39 \pm 0.08$ & $0.37 \pm 0.19$ & $0.02 \pm 0.02$ & $22: 1$ \\
\hline
\end{tabular}

consisted of a filter band $(9 \mu \mathrm{m}$ pore size, $1 \mathrm{~cm}$ deep $x$ $2.7 \mathrm{~cm}$ external diameter $\times 12.3 \mathrm{~cm}^{2}$ surface area) mounted on a hollow support. Extracting a $10 \mathrm{ml}$ sample of pore water in sediment with a porosity of 0.7 would draw water from $14.3 \mathrm{~cm}^{3}$ of sediment, $86 \%$ of which would be contained in the $12.3 \mathrm{~cm}^{3}$ ring of sediment immediately around the filter. Maximum pore water intrusion from sediment horizons above or below the designated depth would be between 0.3 and $1 \%$ (of the total $10 \mathrm{ml}$ sample) depending on porosity. Extraction of a sufficient volume $(10 \mathrm{ml})$ of pore water was usually complete after 5 to $10 \mathrm{~min}$. depending on sediment type. On 3 occasions pore water samples were taken at the same depth at approximately $1 \mathrm{~h}$ intervals over a period of $4 \mathrm{~h}$ to look for changes in pore water nutrient pools. Extracted water samples were preserved with mercuric chloride solution $(100 \mu \mathrm{l}, 0.2 \% \mathrm{w} / \mathrm{v}$; Kirkwood 1992) and subsequently ana-lysed for $\mathrm{NO}_{3}^{-}, \mathrm{NO}_{2}^{-}$, $\mathrm{NH}_{4}{ }^{+}, \mathrm{SiO}_{3}$ and $\mathrm{PO}_{4}{ }^{3-}$ (Kirkwood 1996).

Rate measurements. Sediment-water nutrient exchange and oxygen uptake: For logistical reasons, sediment-water nutrient exchange and oxygen uptake measurements were made at sites 4 and 7 independently to those at the other sites. Site 4 was selected to continue for a further year the data set obtained in 1992 to 1993 (Nedwell \& Trimmer 1996), thus giving interannual comparisons. Site 7 was selected as it represented the sediment that was most strikingly different to those measured in the upper estuarine study (Nedwell \& Trimmer 1996). Triplicate sediment cores $(\sim 20 \mathrm{~cm}$ deep) and overlying water $(\sim 1)$ were collected from sites 4 and 7 to measure sediment-water nutrient exchange $\left[\mathrm{NO}_{3}{ }^{-}, \mathrm{NO}_{2}{ }^{-}\right.$, and $\mathrm{NH}_{4}{ }^{+}$on all occasions, and for urea in July 1994, according to the methods described in Nedwell \& Trimmer (1996)\} and oxygen uptake rates in the dark using dissolved oxygen electrodes and data logging equipment as described by Nedwell \& Trimmer (1996). At sites 5, 6, 8 and 9 , nutrient fluxes (as above) were measured on a bimonthly basis during the acetylene blockage denitrification assay (see below).

Five sediment cores $(-20 \mathrm{~cm}$ deep) were collected just before low tide from sites 10, 11 and 12 using perspex tubes $(30 \mathrm{~cm}$ long $\times 10 \mathrm{~cm}$ i.d.), sealed underneath with an adjustable piston and carried back to the mobile laboratory on the flat-bottomed boat. Site water $(\sim 750 \mathrm{ml})$ was carefully introduced over the sediment and the tube capped. The core samples were then incubated with gentle aeration at in situ temperature in a water bath in the dark. After $2 \mathrm{~h}$, a water sample $(10 \mathrm{ml})$ was withdrawn, filtered $(0.2 \mu \mathrm{m}$ Minisart Plus ${ }^{\mathrm{TM}}$, Sartorius UK Ltd) and fixed (as above) prior to analyses. Water samples then were continued to be taken every $4 \mathrm{~h}$ up to $24 \mathrm{~h}$. All water samples were analysed for $\mathrm{NO}_{3}{ }^{-}, \mathrm{NO}_{2}{ }^{-}, \mathrm{NH}_{4}{ }^{+}, \mathrm{SiO}_{3}$ and $\mathrm{PO}_{4}{ }^{3-}$ according to Kirkwood (1996).

Denitrification rates measured by acetylene blockage: Nine small sediment cores $(\sim 10 \mathrm{~cm}$ deep) and overlying water $(\sim 100 \mathrm{ml})$ were collected at low tide from sites 4 to 9, at bimonthly intervals, from May 1994 until March 1995, using small perspex core tubes $(20 \mathrm{~cm}$ long $\times 3.4 \mathrm{~cm}$ i.d.) sealed with a rubber bung. Denitrification rates were measured as described by Ogilvie et al. (1997) using acetylene-saturated site water injected into the surface $1 \mathrm{~cm}$ of sediment and incubated in the dark at in situ temperature for 3 to $6 \mathrm{~h}$, depending on the time of year and the rate of oxygen uptake. The reader is referred to Ogilvie et al. (1997) for a detailed discussion of measuring denitrification by acetylene blockage.

Calculation of sedimentary $\mathbf{C}$ and $\mathbf{N}$ budget. The calculation of the sedimentary $\mathrm{C}$ and $\mathrm{N}$ budgets requires several assumptions to be made. Firstly, that $\mathrm{C}$ and $\mathrm{N}$ were mineralised in proportion to the $\mathrm{C}: \mathrm{N}$ ratio of the sediment (Blackburn et al. 1988). However, 
sedimentary organic matter determinations do not discriminate between the amounts of labile or refractory organic matter present (Nedwell 1987) and may therefore give little indication of the amount of microbially available organic matter at each site. Secondly, that all of the sulphide formed from $\mathrm{SO}_{4}{ }^{2-}$ reduction was reoxidised before release from the sediment surface (Jørgensen 1977, 1982, Blackburn et al. 1988, Nedwell et al. 1993) and that permanent sulphide burial was minimal (Nedwell \& Trimmer 1996). Studies have shown that only a small proportion $(<1$ and $7 \%$ ) of sedimentary $\mathrm{SO}_{4}{ }^{2-}$ reduction is released from sediments as sulphide (Ingvorsen \& Jørgensen 1982 and Marnette et al. 1992, respectively). Thirdly, that pore water concentrations of $\mathrm{SO}_{4}{ }^{2-}$ were high enough to prevent methanogenesis, although this may not always be the case (Wellsbury et al. 1996). Fourthly, that $\mathrm{N}_{2}$ fixation was small compared to the total sedimentary flux of $N$ (Abd Aziz \& Nedwell 1988). Whereas Hargrave \& Philips (1981) measured a total efflux of $\mathrm{CO}_{2}$ equivalent to 2.5 times the rate of oxygen uptake, both Mackin \& Swider (1989) and Boucher et al. (1994) measured an almost 1:1 relationship between oxygen uptake and $\mathrm{CO}_{2}$ production, suggesting that measures of oxygen uptake can provide realistic estimates of total sediment respiration.

The measured rates of denitrification by acetylene blockage $\left(D_{w}\right)$ were taken to be equivalent to the amount of $\mathrm{NO}_{3}^{-}$uptake being reduced to $\mathrm{N}_{2}$ gas. The mineralisation of organic $\mathrm{C}$ and $\mathrm{N}$ via $\mathrm{NO}_{3}{ }^{-}$reduction to gases was then calculated using the stoichiometries given in Nedwell \& Trimmer (1996) and the measured $\mathrm{C}: \mathrm{N}$ ratios of the sediment. The difference between the rate of denitrification $\left(D_{\mathrm{w}}\right)$ and $\mathrm{NO}_{3}{ }^{-}$uptake was taken to represent the rate of $\mathrm{NO}_{3}{ }^{-}$ammonification and mineralisation of organic $\mathrm{C}$ and $\mathrm{N}$ via $\mathrm{NO}_{3}{ }^{-}$ammonification, was calculated as:

$$
\begin{gathered}
\left(\mathrm{CH}_{2} \mathrm{O}\right)_{106}\left(\mathrm{NH}_{3}\right)_{16}+53 \mathrm{HNO}_{3}= \\
106 \mathrm{CO}_{2}+69 \mathrm{NH}_{3}+53 \mathrm{H}_{2} \mathrm{O}
\end{gathered}
$$

The total amount of $\mathrm{NH}_{4}{ }^{+}$generated by the above calculations was then compared to the actual measured $\mathrm{NH}_{4}{ }^{+}$flux and any deficit or excess in the $\mathrm{NH}_{4}{ }^{+}$ budget calculated. The annual rates of $\mathrm{O}_{2}$ uptake at sites 4 and 7 , in conjunction with the measured $C: N$ ratios of the sediment, were used to calculate, stoichiometrically, the organic mineralisation via $\mathrm{O}_{2}$ and $\mathrm{SO}_{4}{ }^{2-}$ respiration at these 2 sites (stoichiometries given in Nedwell \& Trimmer 1996). The annual rates of $\mathrm{O}_{2}$ uptake at sites 4 and 7 were then averaged and used to calculate the organic mineralisation via $\mathrm{O}_{2}$ and $\mathrm{SO}_{4}{ }^{2-}$ respiration at sites 5, 6, 8 and 9. Any remaining excess of $\mathrm{N}$ that could not be accounted for by either the measured $\mathrm{NH}_{4}{ }^{+}$flux or by uncoupled denitrification $\left(D_{\mathrm{w}}\right)$ was oxidised and then reduced to $\mathrm{N}_{2}$ gas, and repre- sented organic mineralisation via coupled denitrification $\left(D_{n}\right)$ as (Nedwell \& Trimmer 1996):

$$
\begin{gathered}
\left(\mathrm{CH}_{2} \mathrm{O}\right)_{106}\left(\mathrm{NH}_{3}\right)_{16}+118 \mathrm{O}_{2}= \\
106 \mathrm{CO}_{2}+8 \mathrm{~N}_{2}+130 \mathrm{H}_{2} \mathrm{O}
\end{gathered}
$$

Calculation of freshwater flushing times and attenuation of riverine $\mathbf{N}$ load. At the mouth of the Great Ouse the Wash forms the largest estuary in the UK (666 km² ; Davidson et al. 1991). However, because of the nature of the Great Ouse-Wash interface, defining which region of sediment can be regarded as the Great Ouse estuary is somewhat subjective. We define the area of the Great Ouse estuary (Fig. 1), at high tide, as the region of sediment extending halfway along the shore to the mouth of the River Nene (west) and an equal distance east, out to where maximum seawater salinities (33 psu) were first measured at high tide. An arc with a radius from the immediate mouth of the Great Ouse to the latitude marking the position of 33 salinity was then drawn until it intersected lines extending out at right angles from the east and west boundaries. Subsequent arcs with decreasing radij were drawn to mark various salinity boundaries. The landward extent of the estuary was defined as the region where salinities of $<1$ were measured at high tide. Seasonal surveys indicated that the salinity regime of the estuary was similar throughout most of the year, and it was only during extremely low summer freshwater flows that saline intrusion increased up the estuary at high tide. Based on this calculation the overall area of sediment covered by the estuary at high tide was $50 \mathrm{~km}^{2}$. The $50 \mathrm{~km}^{2}$ was then subdivided into sectors running east to west across the mouth of the Great Ouse, each sector in turn was subdivided into $1 \mathrm{~km}^{2}$ (or fractions of) boxes, giving a total number of around 55 boxes, depending on season. The height and volume of water in each box at high tide were calculated using the depths given in the most recent Imray Chart (Y9, The Wash, Imray Laurie Norie and Wilson Ltd). The ratio of freshwater to saltwater was calculated by assigning each box a salinity value read off the various salinity arcs and in this way the freshwater volume of each sector and in turn the entire estuary could be calculated. The freshwater volume was then compared with representative seasonal freshwater flow rates (Environment Agency unpubl. data) to calculate freshwater flushing times.

The same box model was then used calculate the total rate of denitrification for the entire estuary and in turn the percentage of the TOxN load attenuated. For each high tide survey a linear relationship was fitted to the $\mathrm{NO}_{3}{ }^{-}$and salinity data. This in turn was used to assign a $\mathrm{NO}_{3}{ }^{-}$concentration to each box, given its salinity value. The $\mathrm{NO}_{3}{ }^{-}$concentrations were then used to generate denitrification rates for each box 
using the calculated $k_{m}$ and $V_{\max }$ values (see Fig. 8). Denitrification rates in the sediment became saturated at approximately $400 \mu \mathrm{M} \mathrm{NO}_{3}{ }^{-}$.

\section{RESULTS}

\section{Sediment characteristics}

The sedimentary organic $\mathrm{C}$ and total $\mathrm{N}$ content $(0$ to $2 \mathrm{~cm}$ ) was highest at the muddy sites 7,10 and 11 (Table 1) and lowest at the sandy sites. The organic $\mathrm{C}$ content of the sediment was significantly $(p<0.05)$ correlated with both porosity and total $\mathrm{N}$ content. The average sedimentary $\mathrm{C}: \mathrm{N}$ (molar) ratio in the lower estuary $(15: 1)$ was substantially less than that in the upper estuary (33:1; Nedwell \& Trimmer 1996).

\section{Nutrient and salinity concentrations in the water column}

Nitrate in the estuary varied seasonally, with maximal concentrations (up to $830 \mu \mathrm{M}$ at site 4) during high river flow in January 1995 and minimal concentrations
(6 $\mu \mathrm{M}$ at site 12) during September 1993. In contrast to the clear seasonality for $\mathrm{NO}_{3}{ }^{-}$, the $\mathrm{NH}_{4}{ }^{+}$concentrations fluctuated throughout the year between 0 and $80 \mu \mathrm{M}$. Nitrite and urea (when detectable) were always less than $10 \mu \mathrm{M}$. Highest salinities (33 psu) were measured during the summer at sites 9 and 12 when freshwater flows were restricted and saline intrusion from the Wash was greatest.

\section{Pore water nutrients}

\section{Profiles}

Nitrate concentrations decreased rapidly with depth at sites 10 and 11 (Fig. 2), usually reaching a minimum by $5 \mathrm{~cm}$. Subsurface $\mathrm{NO}_{3}^{-}$peaks between 0 and $5 \mathrm{~cm}$ were occasionally measured at site 12 , indicating nitrification in this more oxic sandy sediment. The overlying water column $\mathrm{NO}_{3}{ }^{-}$concentrations were significantly correlated $(\mathrm{p}<0.05$ ) with the top $1 \mathrm{~cm}$ pore water $\mathrm{NO}_{3}{ }^{-}$concentrations at sites 10 and 11 (as found also in the upper estuary; Nedwell \& Trimmer 1996). Ammonium concentration profiles generally increased with depth at sites 10 to 12 (Fig. 2) and overall $\mathrm{NH}_{4}{ }^{+}$
Fig. 2. Examples of (A) nitrate and (B) ammonium pore water profiles (mean of duplicates) measured at sites $10(\bullet), 11(\mathbf{\square})$ and $12(\mathbf{\Delta})$
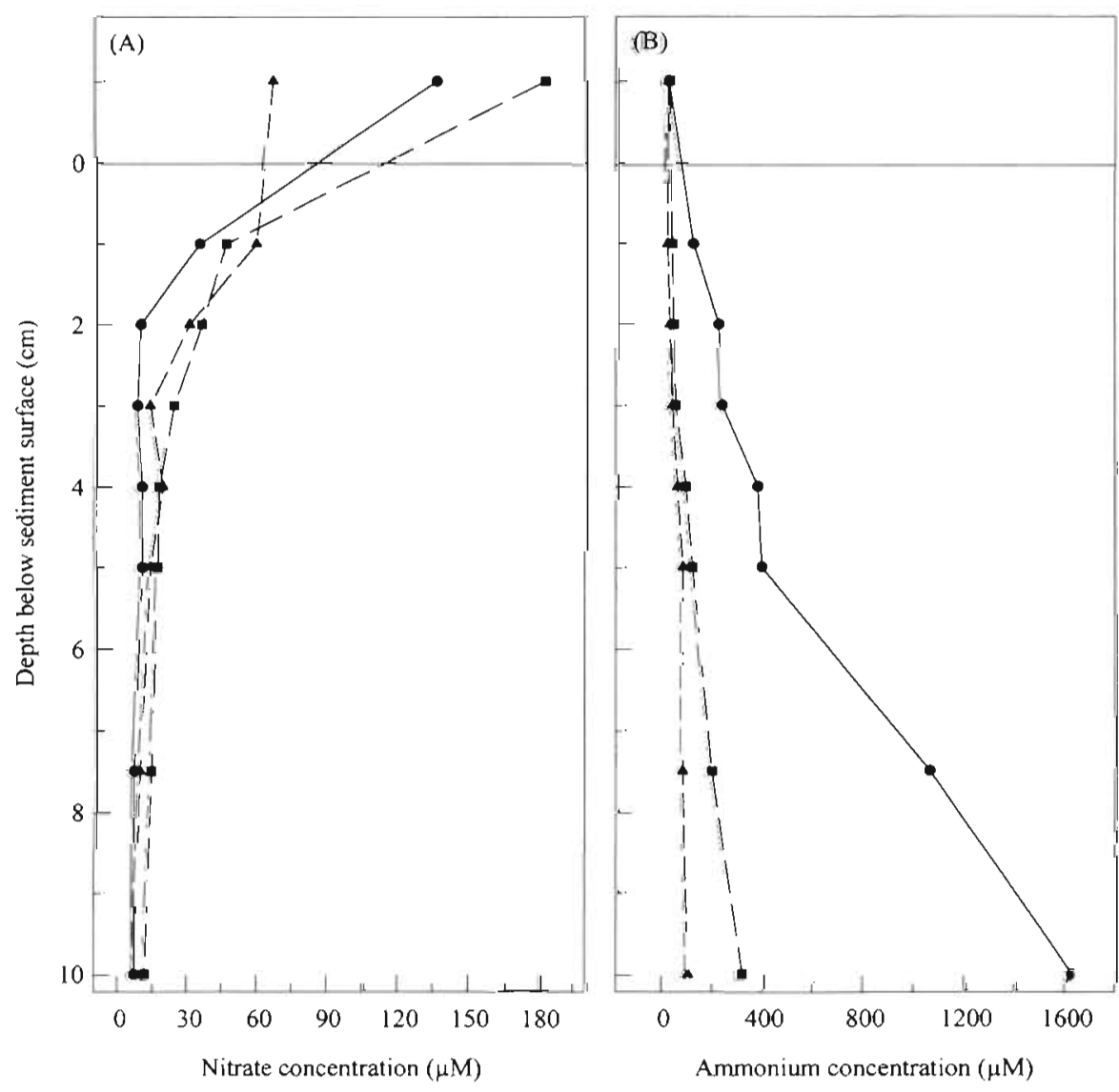

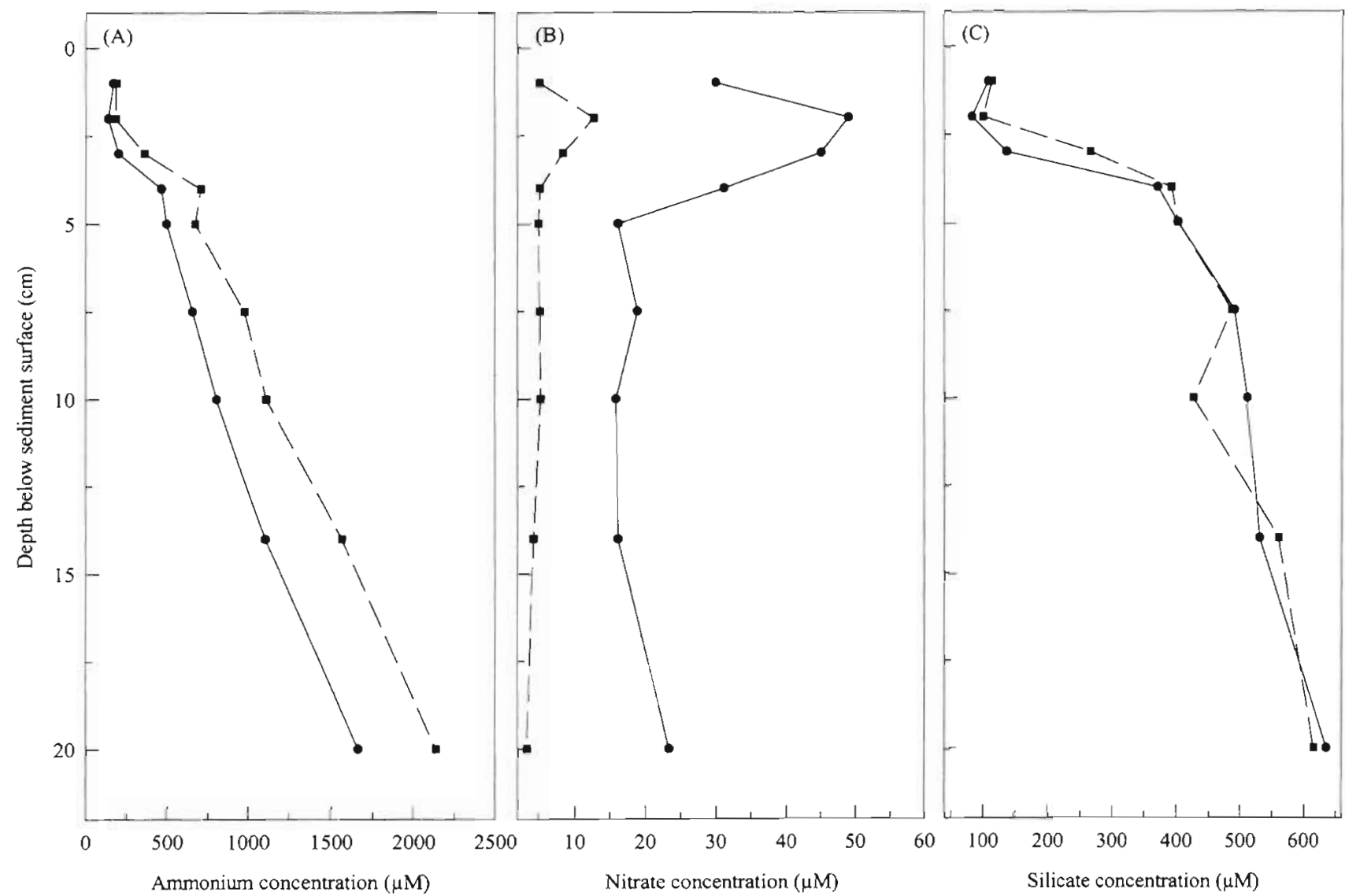

Fig. 3. Examples of singular time series (A) ammonium, (B) nitrate and (C) silicate pore water profiles $T_{0}$ (time zero, $\bullet$ ) and $T_{!}$(time final, a) measured at site 10

concentrations were highest during summer. The $\mathrm{NH}_{4}{ }^{+}$ pore water concentrations were highest at site 10 (up to $2380 \mu \mathrm{M}$ at $10 \mathrm{~cm}$, July 1992), a factor of 10 lower at site 11 and lowest at site 12 (rarely above $100 \mu \mathrm{M}$ at $10 \mathrm{~cm}$ ).

\section{Changes in nutrient pools after exposure}

The time series of pore water profiles showed that sedimentary $\mathrm{NO}_{3}{ }^{-}$concentrations decreased in the exposed sediment at all sites, regardless of sediment type (Fig. 3). Maximum removal of $\mathrm{NO}_{3}^{-}$usually occurred in the first $2 \mathrm{~h}$ after exposure and the rate was significantly correlated with the initial $\mathrm{NO}_{3}{ }^{-}$concentration $(p<0.05)$. In contrast to $\mathrm{NO}_{3}^{-}, \mathrm{NH}_{4}{ }^{+}$pore water concentrations increased with time (Fig. 3) at sites 10 and 11 , with greatest production at site 10 . Although the sediment at site 11 was usually a net source for $\mathrm{NH}_{4}{ }^{+}$, it removed a small amount during June 1994. In contrast the pore water $\mathrm{NH}_{4}{ }^{+}$concentrations decreased consistently with time at site 12 , presumably due to nitrification, as indicated also by the subsurface $\mathrm{NO}_{3}{ }^{-}$ peaks. The fact that the time series of $\mathrm{SiO}_{3}$ pore water concentrations at sites 10 to 12 (Fig. 3) remained constant with time suggested that the changes in $\mathrm{NO}_{3}{ }^{-}$and $\mathrm{NH}_{4}{ }^{+}$concentrations reflected real in situ processes and not intrusion of pore water from surrounding areas.

\section{Oxygen uptake}

Oxygen uptake by the sediments at sites 4 and 7 showed a clear seasonal pattern (Fig. 4), with maximum uptake during the summer and minimum uptake during the winter and early spring. The rate of $\mathrm{O}_{2}$ uptake was significantly correlated $(p<0.05)$ to the sediment temperature at both sites. Analysis of variance (and post hoc Tukey testing) showed that the rates of $\mathrm{O}_{2}$ uptake at the more organic site 7 were only significantly higher $(\mathrm{p}<0.05)$ than site 4 during June and August 1994, and the annually integrated values for $\mathrm{O}_{2}$ uptake were very similar -28 and $21 \mathrm{~mol} \mathrm{O}_{2} \mathrm{~m}^{-2}$ $\mathrm{yr}^{-1}$ respectively. The annual rate of $21 \mathrm{~mol} \mathrm{O}_{2} \mathrm{~m}^{-2} \mathrm{yr}^{-1}$ measured at site 4 during 1994 to 1995 compared well 
with the previous year's value of $23 \mathrm{~mol} \mathrm{O}_{2} \mathrm{~m}^{-2} \mathrm{yr}^{-1}$, indicating interannual reproducibility.

\section{Sediment-water nutrient exchange fluxes}

The flux of $\mathrm{NO}_{3}{ }^{-}$and $\mathrm{NH}_{4}{ }^{+}$across the sediment-water interface at sites 4 to 9 showed no clear seasonal pattern (Fig. 5), but confirmed that the sediments in this lower sector of the estuary were consistent sinks for $\mathrm{NO}_{3}{ }^{-}$and sources of $\mathrm{NH}_{4}{ }^{+}$. On average, for all flux data from sites 4 to 9 , the sediments took up $310 \mu \mathrm{mol} \mathrm{NO}{ }_{3}^{-} \mathrm{m}^{-2} \mathrm{~h}^{-1}$ at a mean $\mathrm{NO}_{3}{ }^{-}$concentration of $425 \mu \mathrm{M}$, and released $270 \mu \mathrm{mol} \mathrm{NH}_{4}{ }^{+}$ $\mathrm{m}^{-2} \mathrm{~h}^{-1}$. At sites 4 to 9 , neither the flux of $\mathrm{NO}_{3}{ }^{-}$to the sediment nor efflux of $\mathrm{NH}_{4}{ }^{+}$from the sediment was significantly correlated either with their respective concentrations in the overlying water or with the sediment temperature. (The single exception was at site 7 where the flux of $\mathrm{NO}_{3}{ }^{-}$to the sediment was significantly correlated with the concentration of $\mathrm{NO}_{3}{ }^{-}$in the overlying water.) Measurements of sediment-water $\mathrm{NO}_{3}{ }^{-}$exchange at the more seaward sites 10,11 and 12 , where the mean $\mathrm{NO}_{3}{ }^{-}$concentration in the water column was only $167 \mu \mathrm{M}$, indicated that these sediments were also consistent sinks for $\mathrm{NO}_{3}{ }^{-}$, but at these outer sites the rates of $\mathrm{NO}_{3}{ }^{-}$exchange to the sediment were significantly correlated $(p<0.05)$ with the concentrations of $\mathrm{NO}_{3}{ }^{-}$in the overlying water (Fig. 6).

The efflux of $\mathrm{NH}_{4}{ }^{+}$from the sediments along the lower estuary peaked at the most highly organic site 7 : annual averages were $82 \mu \mathrm{mol} \mathrm{NH}_{4}{ }^{+} \mathrm{m}^{-2} \mathrm{~h}^{-1}$ at site 4 , $332 \mu \mathrm{mol} \mathrm{NH}_{4}{ }^{+} \mathrm{m}^{-2} \mathrm{~h}^{-1}$ at site 7 and $145 \mu_{\mathrm{mol} \mathrm{NH}}{ }^{+} \mathrm{m}^{-2}$ $\mathrm{h}^{-1}$ at site 9 . The data series for $\mathrm{NH}_{4}{ }^{+}$efflux at sites 10 to 12 was not as extensive as that for the other sites. However, a significant relationship was found between the rate of efflux and sediment temperature $(p<0.05)$, and the maximal effluxes of 100 and $234 \mu \mathrm{mol} \mathrm{NH}_{4}{ }^{+}$ $\mathrm{m}^{-2} \mathrm{~h}^{-1}$ at sites 10 and 11 compared well with the efflux at sites 5 to 7 in the same locality.

Pooling all the summer (May, July and September) $\mathrm{NH}_{4}{ }^{+}$efflux data from sites 4 to 9 revealed a significant $(p<0.05)$ correlation between $\mathrm{NH}_{4}{ }^{+}$efflux and sediment organic $\mathrm{C}$ content, but the relationship was not significant at other times of the year when ammonification of organic matter was less rapid, and probably lim- ited by low temperature rather than organic matter availability. The efflux of $\mathrm{NH}_{4}{ }^{+}$was significantly ( $p<$ $0.05)$, although weakly $(r=0.47)$, correlated with the flux of $\mathrm{NO}_{3}^{-}$to the sediment and most strongly correlated at site $7(\mathrm{r}=0.78)$. No significant urea fluxes were measured at sites 4 to 9 .

\section{Sediment denitrification rates measured by acetylene blockage}

Statistically significant rates of denitrification were measured at sites 4 to 9 on all occasions (Table 2). Although there was no obvious seasonality to these rates of denitrification, maximal denitrification rates (up to $228 \mu \mathrm{mol} \mathrm{N} \mathrm{m}{ }^{-2} \mathrm{~h}^{-1}$ ) were measured at all 6 sites during May 1994. During the summer (May to September 1994), at sites 6 to 9, denitrification was significantly correlated $(\mathrm{p}<0.05)$ with the concentration of $\mathrm{NO}_{3}{ }^{-}$in the water column, but not at sites 4 and 5 where denitrification seemed to be $\mathrm{NO}_{3}^{-}$saturated. Also during the summer, at sites 4 to 9 , denitrification was significantly correlated $(p<0.05)$ to the sediment 


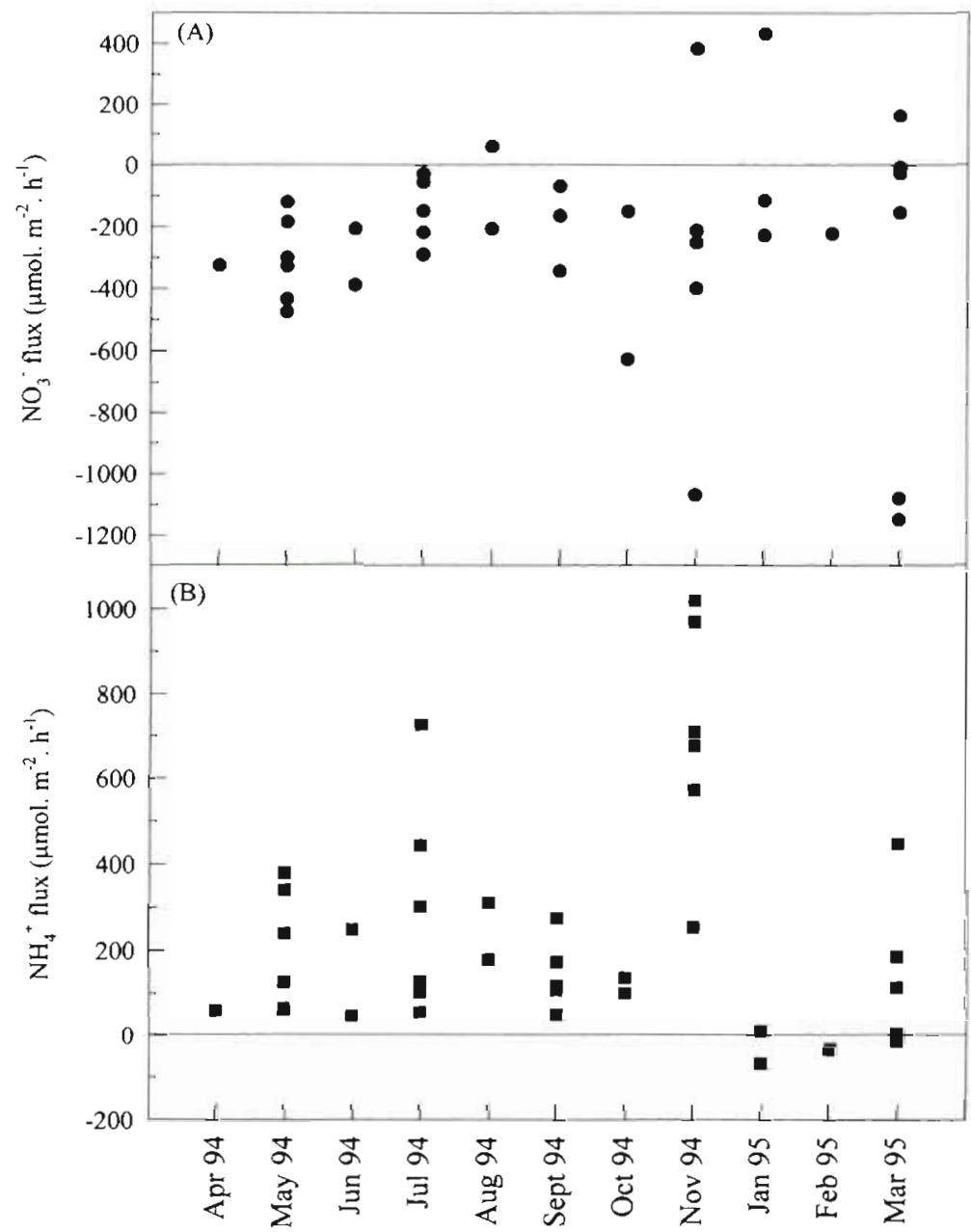

Fig. 5. Seasonality of sediment-water nutrient flux. (A) Nitrate flux (•) and (B) ammonium flux (a) from sites 4 to 9 . Note, not every site was visited on each occasion. Each point is a mean of triplicate determinations at each site, negative values indicate uptake by the sediment, error bars omitted to aid clarity

Table 2. Denitrification rates measured at sites 4 to 9 in the lower Great Ouse estuary using the acetylene block technique ( \pm standard error, $n=3$ ). ns: samples not collected due to bad weather

\begin{tabular}{|lcccccc|}
\hline \multirow{2}{*}{ Date } & \multicolumn{5}{c}{ Denitrification rate $\left(\mu \mathrm{mol} \mathrm{N} \mathrm{m}^{-2} \mathrm{~h}^{-1}\right)$} \\
& Site 4 & Site 5 & Site 6 & Site 7 & Site 8 & Site 9 \\
& & & & & & \\
May 1994 & $158 \pm 28$ & $176 \pm 13$ & $174 \pm 16$ & $228 \pm 22$ & $121 \pm 6$ & $88 \pm 12$ \\
Jul 1994 & $106 \pm 16$ & $166 \pm 15$ & $19 \pm 4$ & $60 \pm 7$ & $37 \pm 4$ & $4 \pm 1$ \\
Sep 1994 & $131 \pm 23$ & $78 \pm 13$ & $45 \pm 8$ & $63 \pm 8$ & $32 \pm 4$ & $9 \pm 1$ \\
Nov 1994 & $81 \pm 12$ & $60 \pm 2$ & $19 \pm 5$ & $84 \pm 16$ & $40 \pm 11$ & $8 \pm 1$ \\
Jan 1995 & $29 \pm 7$ & $\mathrm{~ns}$ & $\mathrm{~ns}$ & $30 \pm 3$ & $\mathrm{~ns}$ & $9 \pm 3$ \\
Mar 1995 & $18 \pm 1$ & $47 \pm 8$ & $42 \pm 5$ & $50 \pm 11$ & $91 \pm 11$ & $15 \pm 1$ \\
& & & & & & \\
\hline
\end{tabular}

between the rates of denitrification at sites 4 and 5 nor, apart from during May 1994 . between sites 4 and 7 . However, denitrification was always significantly lower $(\mathrm{p}<$ $0.05)$ at the more seaward site 9 than at sites 4 and 5 .

\section{DISCUSSION}

\section{Sediment characteristics}

The muddy intertidal sediments of the lower estuary of the Great Ouse (Table 1) were distinctly different to those in the upper estuary (Nedwell \& Trimmer 1996). Whereas the upper estuarine sediments were predominantly fine and very fine sands, the lower intertidal flats were predominantly silt and clay, which suggested that the intertidal flats near the mouth of the Great Ouse were an area of deposition for both organic and inorganic particulate matter. Gould et al. (1987) suggested that the flows in the Great Ouse were such that the sediments are unstable and scoured, causing most of the suspended material to remain in the water column until it reaches the waters seaward of King's Lynn (site 4). This area of deposition coincided with the estuarine turbidity maximum zone, suspended solid loads peaking at $61 \mathrm{mg} \mathrm{l}^{-1}$ at site 4 and decreasing to $13 \mathrm{mg} \mathrm{l}^{-1}$ by $20 \mathrm{~km}$ offshore lannual means, Joint Nutrient Study (JoNuS) database]. The turbidity maximum at site 4 would have been due mainly to 2 processes. Firstly, flocculation of riverborne material occurs at the freshwater-seawater interface; while, secondly, silt and clay deposited on the flats in the lower estuary during the ebb tide are resuspended and carried back up the estuary on the flood tide (Uncles \& Stephens 1993, Forsgren et al. 1996).

\section{Oxygen uptake}

The oxygen uptake rates at sites 4 and 7 (Fig. 4) were similar to those measured in the upper Great Ouse estuary (Nedwell \& Trimmer 1996) and in other estuaries (Jør-

$\mathrm{NO}_{3}{ }^{-}$exchange rates, but not at other times of the year. Analysis of variance (and post hoc Tukey testing) showed that there were no significant differences gensen \& Sørensen 1985, Andersen \& Helder 1987, Binnerup et al. 1992, Yoon \& Benner 1992) and shallow coastal seas (Hopkinson \& Wetzel 1982, Hansen \& 


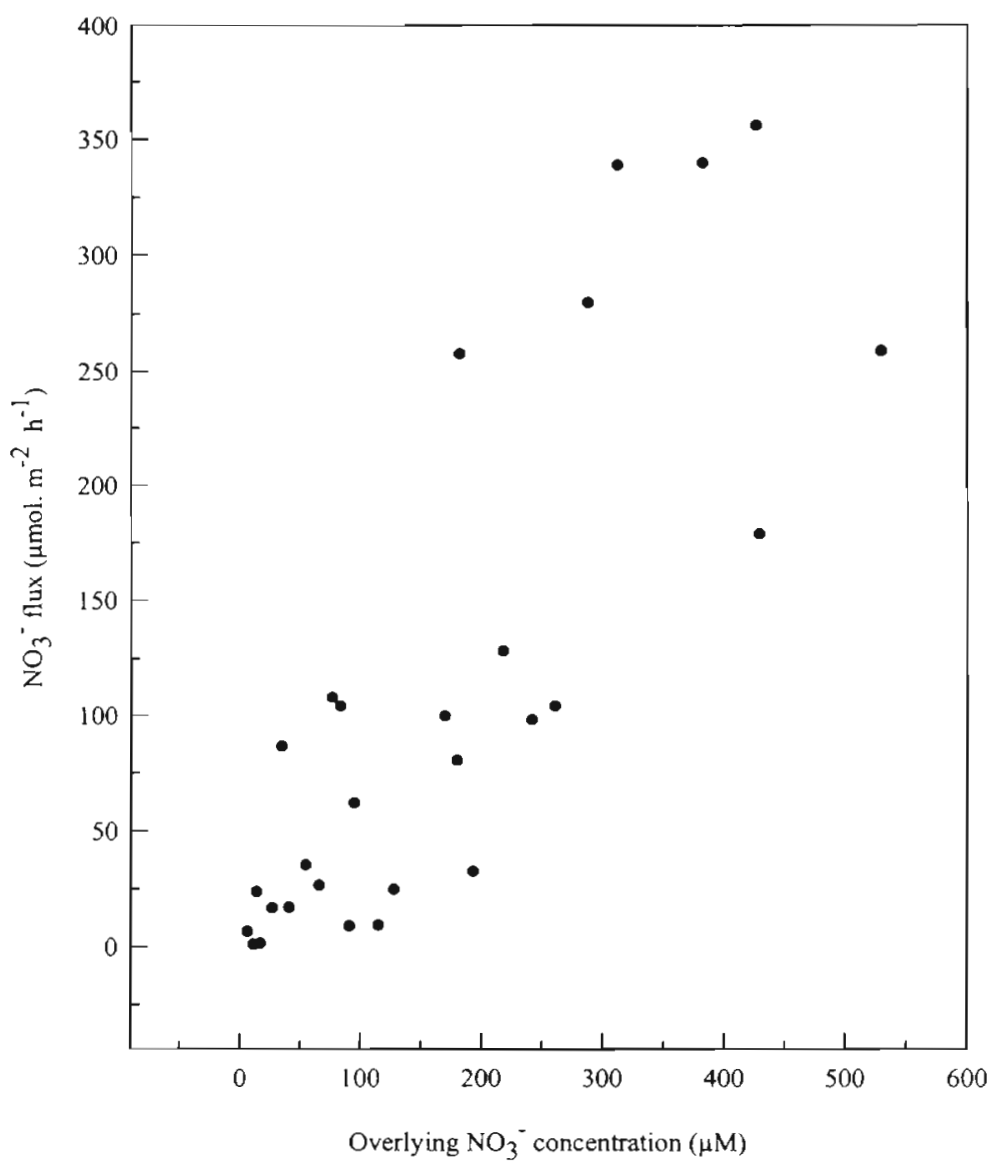

Fig. 6. Scatter plot of nitrate flux against overlying estuarine water column nitrate concentrations at sites 10,11 and $12 . I=0.82(p<0.05)$. Each point is the mean of triplicate determinations

\section{Nutrient exchanges}

Nitrate flux

The $\mathrm{NO}_{3}^{-}$flux measurements showed that the sediments were sinks for $\mathrm{NO}_{3}{ }^{-}$at rates similar to those reported for other estuaries with high $\mathrm{NO}_{3}^{-}$concentrations (Jørgensen \& Sørensen 1985, Jørgensen \& Sørensen 1988, Watson et al. 1993, Ogilvie et al. 1997). When the $\mathrm{NO}_{3}{ }^{-}$flux data from all sites (including sites 1 to 4 in the upper estuary; Nedwell \& Trimmer 1996) were plotted against water column $\mathrm{NO}_{3}{ }^{-}$concentrations, the flux of $\mathrm{NO}_{3}{ }^{-}$became saturated at $\mathrm{NO}_{3}{ }^{-}$concentrations $>400 \mu \mathrm{M}$, at a rate of about $400 \mu \mathrm{mol} \mathrm{NO}_{3}^{-} \mathrm{m}^{-2} \mathrm{~h}^{-1}$ (Fig. 7). Therefore when $\mathrm{NO}_{3}^{-}$loads to the estuary increase, extending the $\mathrm{NO}_{3}{ }^{-}$concentration gradient seawards, the sediments of the outer estuary (e.g. sites 10 to 12) have the capacity to respond by increased rates of $\mathrm{NO}_{3}{ }^{-}$exchange.

To estimate changes of nutrient pools in the sediment after exposure at low tide, the time series of pore water nutrient profiles were integrated with respect to both depth and time. On average, for sites 10 , 11 and $12,76 \%$ of the total amount of $\mathrm{NO}_{3}{ }^{-}$ depletion occurred within the first $2 \mathrm{~h}$ after exposure at low tide. The total area of the Wash is approximately $666 \mathrm{~km}^{2}$ (Davidson et al. 1991) of which $45 \%$ is intertidal. This suggests that an enormous area of sedi-

Blackburn 1991, Nedwell et al. 1993, Upton et al. 1993). The annual $\mathrm{O}_{2}$ uptakes were very similar at sites 4 and 7 ( 21 and $28 \mathrm{~mol} \mathrm{O}_{2} \mathrm{~m}^{-2} \mathrm{yr}^{-1}$ respectively), indicating similar amounts of organic matter mineralisation at each site. The organic $C$ contents and physical characteristics of the sediments at sites 4 and 7 were very different (Table 1), and the similarity between the $\mathrm{O}_{2}$ uptake at each site was surprising. However, sedimentary organic $\mathrm{C}$ determinations do not discriminate between the amounts of labile or refractory organic matter present (Nedwell 1987) and may therefore give little indication of the amount of microbially available organic matter at each site. The similarity between the $\mathrm{O}_{2}$ uptake rates at sites 4 and 7 corroborated the findings in the upper Great Ouse estuary (Nedwell \& Trimmer 1996) and by other workers (Hargrave \& Philips 1981, van Es 1982, Jørgensen \& Sørensen 1985, Andersen \& Helder 1987, Cammen 1991) that temperature rather than sedimentary physical characteristics or organic $\mathrm{C}$ content tends to control sedimentary $\mathrm{O}_{2}$ uptake. ment rapidly processes any $\mathrm{NO}_{3}{ }^{-}$that exchanges into it when inundated at high tide. Hence the intertidal sediment area of the Wash is potentially a very large sink for $\mathrm{NO}_{3}{ }^{-}$and represented a much more significant sink for $\mathrm{NO}_{3}{ }^{-}$than the upper estuary (Nedwell \& Trimmer 1996).

\section{Ammonium flux}

The increase in the sedimentary $\mathrm{NH}_{4}{ }^{+}$efflux from sites 4 to 7 could be due to a number of factors. Firstly, increasing concentrations of sedimentary organic matter lead to higher ammonification rates (Kelly \& Nixon 1984, Kemp \& Boynton 1984, Sloth et al. 1995), as supported by the significant $(p<0.05$ ) correlation during the summer months between the $\mathrm{NH}_{4}{ }^{+}$efflux and the organic content of the sediment. Secondly, as organic matter content increases the ratio of $\mathrm{NO}_{3}{ }^{-}$to organic $\mathrm{C}$ decreases, favouring $\mathrm{NO}_{3}{ }^{-}$ammonification over denitrification (Nedwell 1982, King \& Nedwell 1985). The flux of $\mathrm{NO}_{3}{ }^{-}$into the 


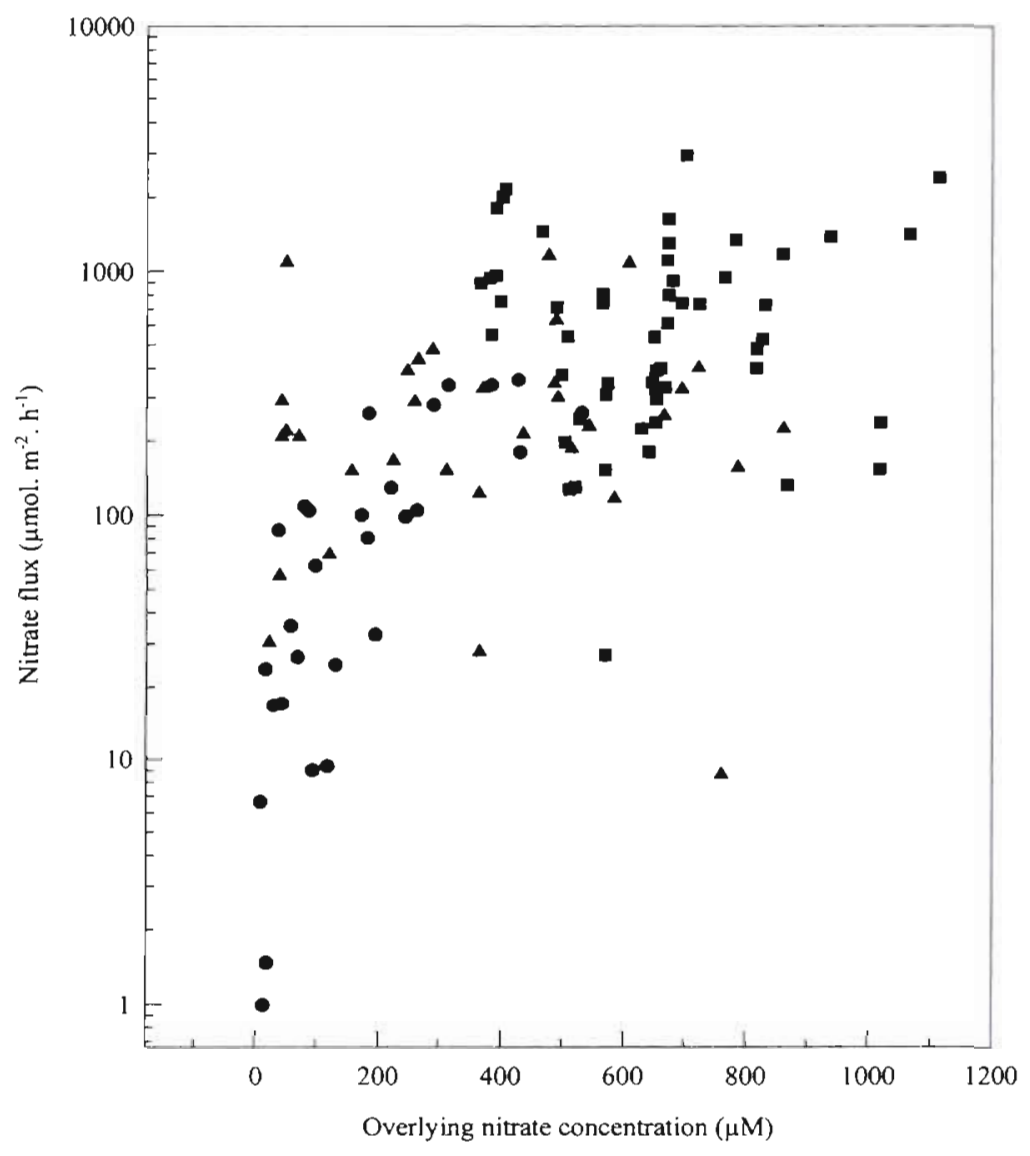

Fig. 7. Scatter plot of nitrate flux (log scale) against overlying estuarine water column nitrate concentrations. ( $\square$ ) Data for sites 1,3 and 4 in the upper estuary (see text), (4) data for sites 4 to 9 and ( $\bullet$ ) data for sites 10,11 and 12 in the lower estuary. Each point is the mean of triplicate determinations

\section{Sediment denitrification rates measured by acetylene blockage}

The flux of $\mathrm{NO}_{3}^{-}$into sediment can be regarded as a measure of the upper limit of possible reduction of $\mathrm{NO}_{3}{ }^{-}$from external sources. The acetylene block assay confirmed that intrusive $\mathrm{NO}_{3}{ }^{-}$from the water column was denitrified to gases in the sediments, the rates (Table 2) being similar to other environments with high concentrations of $\mathrm{NO}_{3}^{-}$(Jørgensen \& Sørensen 1985, Jørgensen \& Sørensen 1988, Koch et al. 1992, Ogilvie et al. 1997). Various studies have correlated peaks of denitrification with maximum concentrations of $\mathrm{NO}_{3}^{-}$(Jørgensen \& Sørensen 1985, Koch et al. 1992, Rysgaard et al. 1995), available organic C (Jørgensen \& Sørensen 1988) and $\mathrm{NO}_{3}{ }^{-}$ transport via bioturbation (Law et al. 1991). There was no clear seasonality to denitrification in the present study but maximum rates occurred during May, when relatively high $\mathrm{NO}_{3}{ }^{-}$concentrations (>380 $\mu \mathrm{M}$ at sites 4 to 9 ) were combined with relatively warm $\left(14^{\circ} \mathrm{C}\right)$ sediment temperatures. Although the sediment temperature peaked later in July $\left(22^{\circ} \mathrm{C}\right)$, by then the $\mathrm{NO}_{3}{ }^{-}$concentrations had fallen below $260 \mu \mathrm{M}$ throughout the estuary. During the spring and summer the rate of $\mathrm{NO}_{3}{ }^{-}$exchange was significantly correlated $(p<0.05)$ to the rate of denitri-

sediment was significantly $(\mathrm{p}<0.05)$ correlated with the efflux of $\mathrm{NH}_{4}{ }^{+}$at all sites in the lower estuary ( $\mathrm{r}=0.47$ ), and the relationship was strongest at site $7(r=0.78)$, where the organic $\mathrm{C}$ content was highest. This suggested that $\mathrm{NO}_{3}{ }^{-}$ammonification was a significant source of $\mathrm{NH}_{4}{ }^{+}$in these sediments. Thirdly, ion pairing in increasingly saline environments can desorb $\mathrm{NH}_{4}{ }^{+}$from the sediment, stimulating the $\mathrm{NH}_{4}{ }^{+}$transport rate and increasing the proportion of $\mathrm{NH}_{4}{ }^{+}$fluxing from the sediment before being nitrified (Blackburn \& Henriksen 1983, Gardner et al. 1991). Fourthly, the ratio of $C$ to $N$ can be relatively low near the surface of marine sediments (Blackburn \& Henriksen 1983), which may increase both the concentration of $\mathrm{NH}_{4}{ }^{+}$in the sediment surface and efflux of $\mathrm{NH}_{4}{ }^{+}$from the sediment surface. However, in contrast to this, in the present study the highest $\mathrm{NH}_{4}{ }^{+}$efflux was measured where the $\mathrm{C}$ to $\mathrm{N}$ ratio of the surface sediment was highest (19C:1N, site 7), suggesting that the $\mathrm{NH}_{4}{ }^{+}$efflux may have been due to ammonification of the $\mathrm{NO}_{3}{ }^{-}$exchanged and not benthic organic $\mathrm{N}$ mineralisation. fication and the gradient of the relationship suggested that for each mole of $\mathrm{NO}_{3}{ }^{-}$reduced, only $28 \%$ was subsequently denitrified. This suggested that during the spring and summer, $\mathrm{NO}_{3}^{-}$ammonification predominated over denitrification (King \& Nedwell 1984, Jørgensen 1989). The annually integrated values for $\mathrm{NO}_{3}{ }^{-}$exchange and denitrification (Table 3) suggested, that on average, $46 \%$ of the $\mathrm{NO}_{3}{ }^{-}$exchanged was denitrified.

During the spring and summer, denitrification was significantly correlated ( $\mathrm{p}<0.05$ ) to the concentration of $\mathrm{NO}_{3}{ }^{-}$in the overlying water at sites 6 to 9 but not at sites 4 and 5. However, no such correlation was found at any site for the autumn and winter data. This suggested that throughout the year at sites 4 and 5 , or at sites 6 to 9 during the winter, denitrification was saturated with $\mathrm{NO}_{3}{ }^{-}$. For the pooled spring and summer denitrification and $\mathrm{NO}_{3}{ }^{-}$concentration data a Michaelis-Menten hyperbolic model explained more of the variance than a first order linear regression, i.e. $r^{2}=0.59$ and 0.69, respectively (Fig. 8). This suggested 
Table 3. Annual nitrogen budget for the lower Great Ouse estuary. (All flux values are mol $\mathrm{m}^{-2} \mathrm{yr}^{-1}$.) Amm.: ammonification; denit.: denitrification; tot.: total; min: mineralised

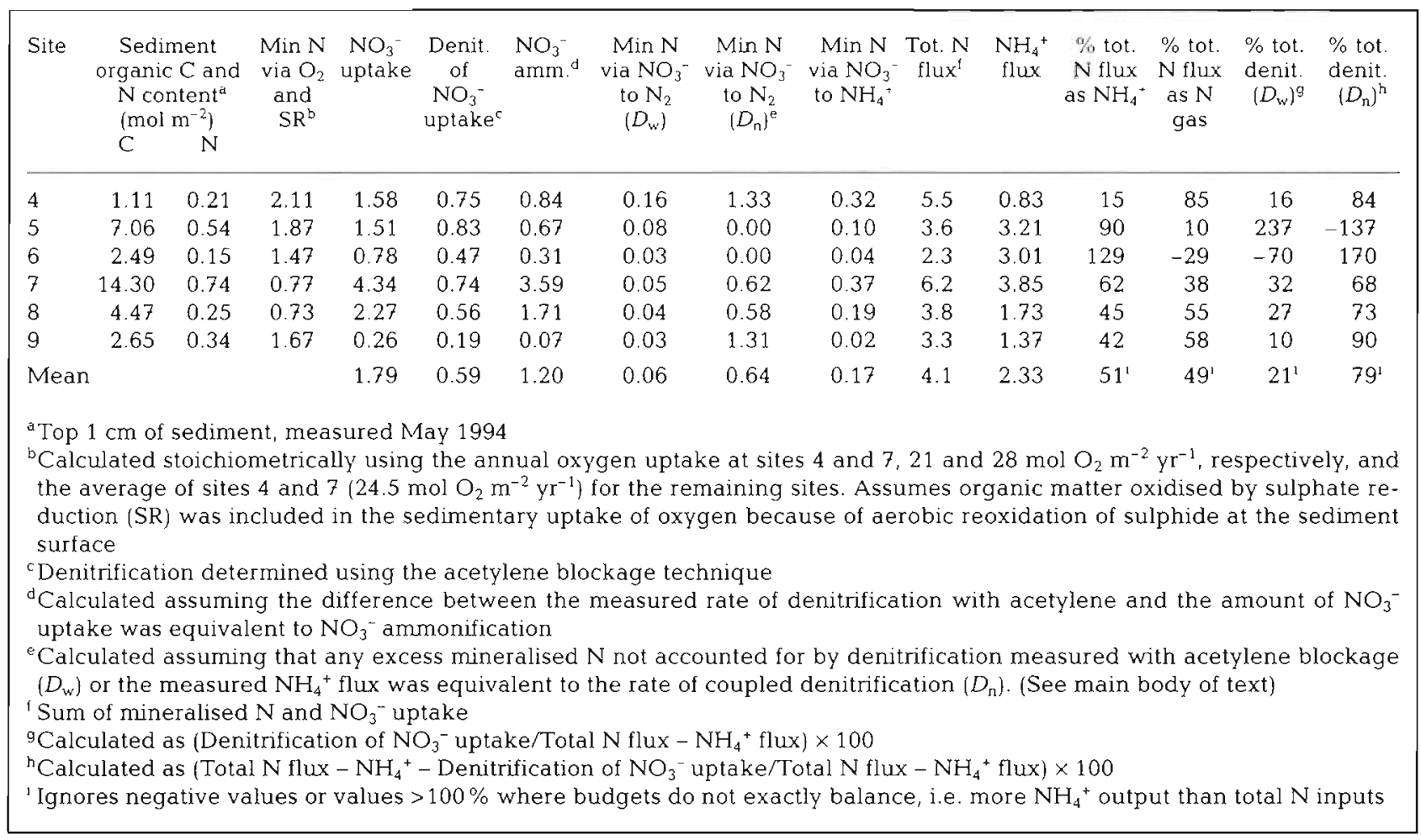

that at $\mathrm{NO}_{3}{ }^{-}$concentrations in excess of $400 \mu \mathrm{M}$ denitrification became saturated at approximately 160 to $250 \mu \mathrm{mol} \mathrm{N} \mathrm{m}^{-2} \mathrm{~h}^{-1}$. A similar maximum rate of $230 \mu \mathrm{mol} \mathrm{N} \mathrm{m}^{-2} \mathrm{~h}^{-1}$ was reported during the winter by Koch et al. (1992) for tidal mudflat sediments. Although in the autumn and winter $\mathrm{NO}_{3}{ }^{-}$concentrations were maximal in the Great Ouse (up to $830 \mu \mathrm{M} \mathrm{NO}_{3}^{-}$at site 4), denitrification was not correlated with $\mathrm{NO}_{3}{ }^{-}$ (Fig. 8) presumably because denitrification became temperature-dependant rather than $\mathrm{NO}_{3}{ }^{-}$-limited (Kaplan et al. 1977, Jørgensen \& Sørensen 1988).

\section{Sedimentary $\mathrm{C}$ and $\mathrm{N}$ budget}

\section{Carbon flux}

Table 4 summarises the proportion of sedimentary organic $\mathrm{C}$ mineralisation driven by each electron acceptor flux at sites 4 to 9 in the lower estuary. Carbon flow was dominated by the respiration of $\mathrm{O}_{2}$ and $\mathrm{SO}_{4}{ }^{2-}$ (76 to $95 \%$ ) as reported elsewhere (Sørensen et al. 1979, Howes et al. 1984, Jørgensen \& Sørensen 1985, Nedwell et al. 1993, 1994, Upton et al. 1993, Nedwell \& Trimmer 1996). Nitrate reduction (both denitrification and $\mathrm{NO}_{3}^{-}$ammonification) accounted for between
5 and $25 \%$ of the $\mathrm{C}$ flux and was greatest at site 7 . The proportion of organic $\mathrm{C}$ oxidation driven by denitrification from externally derived $\mathrm{NO}_{3}^{-}\left(D_{\mathrm{w}}\right.$ average $\left.2 \%\right)$ was low compared to the upper estuary (18\%; Nedwell \& Trimmer 1996). A greater proportion of organic C oxidation was driven by coupled denitrification $\left(D_{\mathrm{n}}\right.$ average $5 \%$ ). However, overall, the proportion of organic $\mathrm{C}$ oxidation driven by denitrification was low $(8 \%)$ compared to $\mathrm{O}_{2}$ and $\mathrm{SO}_{4}{ }^{2-}$ respiration, corroborating the general hypothesis that denitrification plays only a minor role in the oxidation of organic $C$ in estuarine and marine sediments (Sørensen et al. 1979, Jørgensen \& Sørensen 1985, Nedwell et al. 1994).

\section{Nitrogen flux}

The total sedimentary $\mathrm{N}$ budget of the lower estuary (Table 3) was taken to be the $\mathrm{NO}_{3}{ }^{-}$flux to the sediment, the subsequent organic $\mathrm{N}$ mineralised via $\mathrm{NO}_{3}{ }^{-}$reduction, plus organic $\mathrm{N}$ mineralised via aerobic mineralisation and $\mathrm{SO}_{4}{ }^{2-}$ reduction. Assuming steady state, any $\mathrm{N}$ inputs must be balanced by $N$ outputs (Nedwell \& Trimmer 1996). In some circumstances DON export from sediment can be high, but these tend to be either where there are active beds of benthic macrofauna (e.g. Enoks- 
Table 4. Annual organic carbon (OC) budget for the lower Great Ouse estuary. (All flux values are $\mathrm{mol} \mathrm{m}^{-2} \mathrm{yr}^{-1}$.) Amm : ammonification; denit.: denitrification; tot.: total; min: mineralised

\begin{tabular}{|c|c|c|c|c|c|c|c|c|c|c|c|c|c|c|}
\hline Site & $\begin{array}{r}\text { Sed } \\
\text { organi } \\
\mathrm{N} \mathrm{co} \\
\text { (mol } \\
\mathrm{C}\end{array}$ & $\begin{array}{l}\text { ent } \\
C \text { and } \\
\text { tent } \\
m^{-2} \text { ) } \\
\quad N\end{array}$ & $\begin{array}{c}\mathrm{OC} \min \\
\text { and via } \\
\mathrm{O}_{2} \text { and } \\
\mathrm{SR}^{\mathrm{b}}\end{array}$ & $\begin{array}{c}\mathrm{NO}_{3}^{-} \\
\text {uptake }\end{array}$ & $\begin{array}{c}\text { Denit. } \\
\text { of } \\
\mathrm{NO}_{3} \\
\text { uptake }\end{array}$ & $\begin{array}{l}\text { OC min } \\
\text { via } \\
\mathrm{NO}_{3}^{-} \\
\text {to } \mathrm{N}_{2} \\
\left(D_{\mathrm{w}}\right)^{\mathrm{c}}\end{array}$ & $\begin{array}{c}\text { OC min } \\
\text { via } \\
\mathrm{NO}_{3} \\
\text { to } \mathrm{N}_{2} \\
\left(D_{1}\right)^{\mathrm{d}}\end{array}$ & $\begin{array}{c}\mathrm{OCmin} \\
\text { via } \\
\mathrm{NO}_{3}^{-} \\
\text {to } \mathrm{NH}_{4}{ }^{+e}\end{array}$ & $\begin{array}{l}\text { Tot. C } \\
\text { flux }\end{array}$ & $\begin{array}{l}\% \mathrm{OC} \\
\text { min via } \\
\mathrm{O}_{2} \text { and } \\
\mathrm{SR}\end{array}$ & $\begin{array}{c}\% \text { OC } \\
\text { min via } \\
\mathrm{NO}_{3} \\
\text { to } \mathrm{N}_{z} \\
\left(D_{w}\right)\end{array}$ & $\begin{array}{c}\% \text { OC } \\
\text { min via } \\
\mathrm{NO}_{3}^{-} \\
\text {to } N_{2} \\
{\left[D_{n}\right]}\end{array}$ & $\begin{array}{c}\% \mathrm{OC} \\
\text { min via } \\
\mathrm{NO}_{3}^{-} \\
\text {to } \mathrm{NH}_{4}{ }^{+}\end{array}$ & $\begin{array}{c}\% \text { tot.. } \\
\text { OC min } \\
\text { via } \\
\mathrm{NO}_{3}^{-}\end{array}$ \\
\hline 4 & 1.11 & 0.21 & 21.0 & 1.6 & 0.8 & 0.8 & 4.0 & 1.7 & 27.5 & 76 & 3 & 15 & 6 & 24 \\
\hline 5 & 7.06 & 0.54 & 24.5 & 1.5 & 0.8 & 1.0 & 0. & 1.4 & 26.8 & 9 & 4 & 0 & 5 & 9 \\
\hline 6 & 2.49 & 0.15 & 24.5 & 0.8 & 0.5 & 0.6 & 0. & 0.6 & 25.7 & 9 & 2 & 0 & 2 & 5 \\
\hline 7 & 14.30 & 0.74 & 28.0 & 4.3 & 0.7 & 0.9 & 1.3 & 7.2 & 37.4 & 7 & 2 & 3 & 19 & 25 \\
\hline 8 & 4.47 & 0.25 & 24.5 & 2.3 & 0.6 & 0.7 & 1.2 & 3.4 & 29.8 & 82 & 2 & 4 & 11 & 18 \\
\hline 9 & 2.65 & 0.34 & 24.5 & 0.3 & 0.2 & 0.2 & 1.9 & 0.1 & 26.8 & 92 & 1 & 7 & 1 & 8 \\
\hline Mean & & & & 1.8 & 0.6 & 0.7 & 1.4 & 2.4 & 29.0 & 85 & 2 & 5 & 8 & 15 \\
\hline \multicolumn{15}{|c|}{ 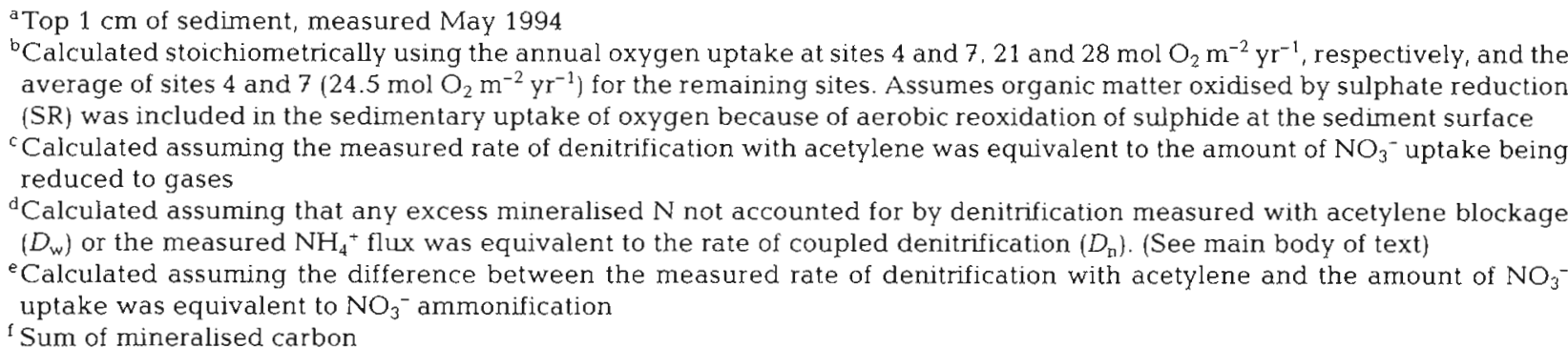 } \\
\hline
\end{tabular}

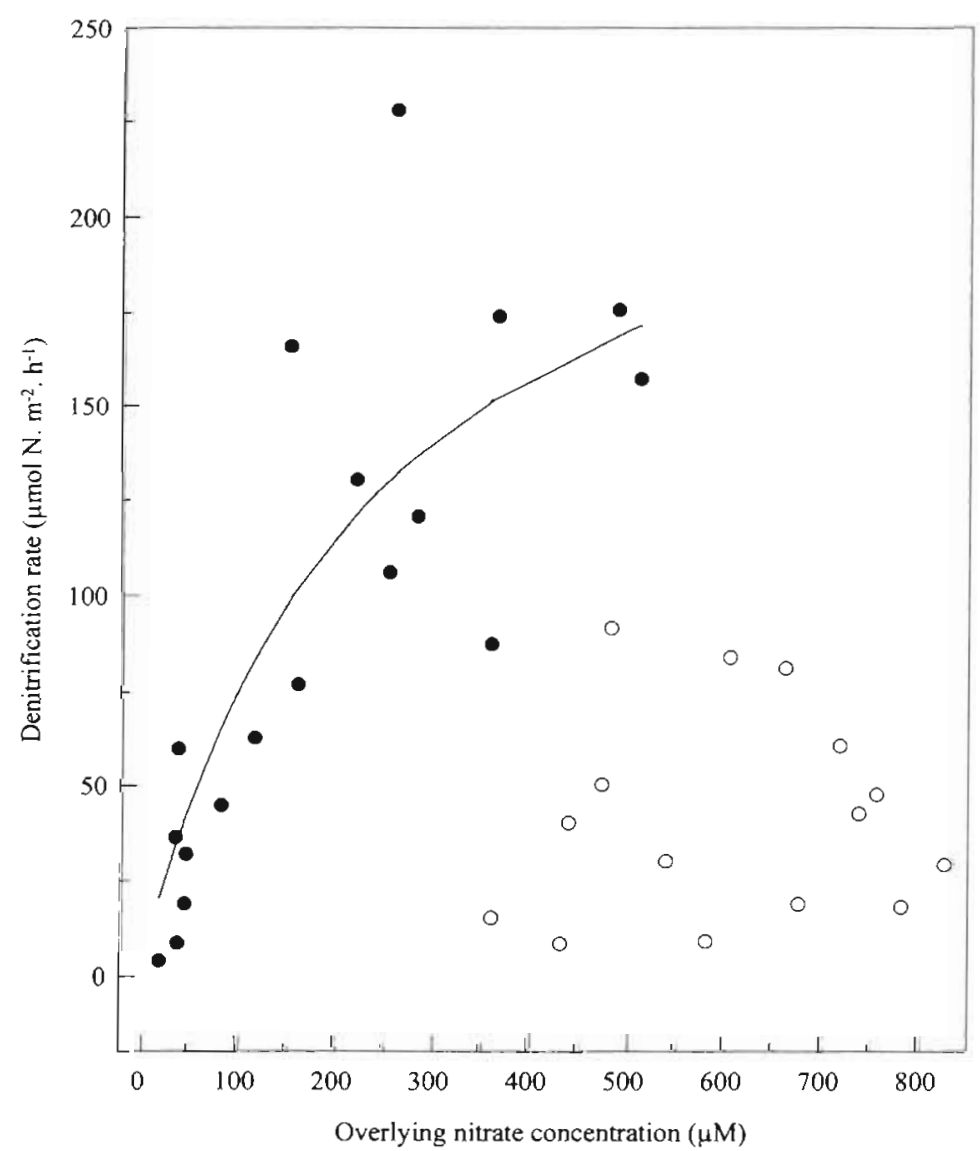

son \& Samuelsson 1987, Hopkinson 1987, Boucher \& Boucher-Rodoni 1988, Lomstein et al. 1989) or where there is temporary input of labile organic matter (e.g. Enoksson \& Rüdén-Berg 1983, Hansen \& Blackburn 1991, Sloth et al. 1995). However, export of DON is predominantly as urea (Boucher \& BoucherRodoni 1988), which we tested for at sites 4 to 9 but did not detect. It was therefore assumed that urea, and by implication DON, was not a significant component of the overall sedimentary $\mathrm{N}$ budget. Risgaard-Petersen et al. (1994) reported a complete cessation of $\mathrm{NH}_{4}{ }^{+}$efflux for sediment colonised by microphytobenthos incubated in the light. Such findings could have serious implications for exchange measurements based on dark incubations. However, in the Great Ouse no mats of microphy-

Fig. 8. Denitrification against overlying estuarine nitrate concentrations at sites 4 to 9 . ( Data measured in spring and summer; lines represent data fitted to Michaelis-Menten function, $V=$ $V_{\max }\left[S /\left(S+k_{m}\right)\right], r^{2}=0.69(p<0.05)$. (0) Data measured in autumn and winter; no significant relationships. Each point is the mean of triplicate determinations 
tobenthos were visibly present. Subsequent seasonal measurements of both light and dark nutrient exchange and of chlorophyll a showed that light had no significant effect on the nutrient flux and that concentrations of chlorophyll a were consistently $<3 \mu \mathrm{g} \mathrm{g}^{-1}$ dry sediment (data not shown).

In the upper estuary the $\mathrm{NH}_{4}{ }^{+}$efflux accounted for only $8 \%$ of the total sedimentary $\mathrm{N}$ flux (Nedwell \& Trimmer 1996), but in the lower estuary accounted for $51 \%$. In the upper estuary (Nedwell \& Trimmer 1996) mineralised $\mathrm{N}$, derived from the oxidation of organic matter by $\mathrm{O}_{2}$ and $\mathrm{SO}_{4}{ }^{2-}$ respiration, accounted for $15 \%$ of total benthic $\mathrm{N}$ flux, but for $40 \%$ (average for all sites) in the lower estuary. The greater significance of the $\mathrm{NH}_{4}{ }^{+}$efflux in the lower estuary, compared to the upper estuary, can be related in part to their different sediment $C: N$ ratios (molar). In the upper estuary the average $C: N$ ratio was $33: 1$ compared to $15: 1$ in the lower estuary. Oxidation of organic matter with these $\mathrm{C}: \mathrm{N}$ ratios will result in a greater amount of organically bound $\mathrm{N}$ being ammonified from the organic matter with the lower $\mathrm{C}: \mathrm{N}$ ratio. In addition to this, if the difference between the total flux of $\mathrm{NO}_{3}{ }^{-}$to the sediment and the rate of uncoupled denitrification was used as a measure of $\mathrm{NO}_{3}{ }^{-}$ammonification (see above), $\mathrm{NO}_{3}{ }^{-}$ ammonification could, on average, account for $55 \%$ of the annual $\mathrm{NH}_{4}^{+}$efflux at sites 4 to 9 . At site $7, \mathrm{NO}_{3}{ }^{-}$ ammonification could account for $93 \%$ of the annual $\mathrm{NH}_{4}{ }^{+}$efflux and at this site the organic $\mathrm{C}$ content was highest and the correlation between the flux of $\mathrm{NO}_{3}{ }^{-}$to the sediment and flux of $\mathrm{NH}_{4}{ }^{+}$from the sediment was strongest $(\mathrm{r}=0.78)$. Under such conditions $\mathrm{NO}_{3}{ }^{-}$reduction to $\mathrm{NH}_{4}{ }^{+}$, rather than to gases, would have been favoured (Koike \& Hattori 1978, Nedwell 1982, King \& Nedwell 1985)

In order for the steady state $\mathrm{N}$ budget to balance, it was assumed that any $\mathrm{N}$ not accounted for as either $\mathrm{NH}_{4}{ }^{+}$or lost via uncoupled denitrification must have been lost via the coupling of nitrification to denitrification. The discrepancy between the total sedimentary $N$ flux and that measured effluxing from the sediment as $\mathrm{NH}_{4}{ }^{+}$suggested that, on an annual basis, $49 \%$ of the $\mathrm{N}$ flux was denitrified and lost from the sedimentary system as $\mathrm{N}$ gases (Table 3 ). There was therefore a distinct difference between the $\mathrm{N}$ budget of the lower estuary compared to the upper, where $>90 \%$ of the total benthic $N$ flux was denitrified and lost from the sedimentary system as $\mathrm{N}$ gases (Nedwell \& Trimmer 1996). Benthic primary production, coupled to the settlement from the water column of both pelagic primary production and riverine inputs of organic matter, contributes to sedimentary organic matter and therefore to the overall loss of $\mathrm{N}$ within the estuary either by direct (uncoupled) or coupled denitrification. The estuary would therefore appear to have a large potential, as a filter, to attenuate the $\mathrm{N}$ flux through the estuary. This filter or 'processing zone' in the Great Ouse estuary is concentrated in the sediment region of the turbidity maximum, seaward of site 4 .

The sedimentary $N$ budget of the lower estuary (Table 3) demanded that $79 \%$ of the total amount of denitrification was driven by coupled nitrificationdenitrification $\left(D_{n}\right)$. This value is high compared to others reported in the literature. For example, RisgaardPetersen et al. (1994) reported values for coupled denitrification $\left(D_{n}\right)$ of between 4 and $16 \%$ and Nielsen (1992) approximately 19 to $42 \%$. However, Ogilvie et al. (1997) reported values for $D_{\mathrm{n}}$ of between 31 and $69 \%$. This suggests that the high rates of $D_{n}$ reported in this study, whilst high, are at least possible. The alternative is that budgetry calculations based on average sedimentary $C: N$ ratios do not accurately reflect in situ mineralisation rates of organic material. Therefore the budgetary calculations reported in this study generated an artifically high excess of $\mathrm{NH}_{4}{ }^{+}$and in turn high rates of $D_{\mathrm{n}}$

\section{Freshwater flushing times and attenuation of riverine $\mathrm{N}$ load}

Freshwater flushing times (i.e. the time taken for the freshwater in an estuary to be replaced with 'new' freshwater) for the Great Ouse estuary ranged from $25 \mathrm{~d}$ in July to $2 \mathrm{~d}$ in January (1992 data). Nixon et al. (1996) presented freshwater residence times for numerous estuaries. However, it was difficult to compare our calculations of freshwater flushing times for the Great Ouse estuary with the Nixon et al. (1996) data because of confusion over definitions in the literature, i.e. flushing rate, mean freshwater replacement time, mean residence time and freshwater flushing time. If these terms in fact describe similar estuarine processes, then the Great Ouse is similar in terms of residence times to Boston Harbour (USA), Narragansett Bay (USA), Norsminde Fjord (Denmark) and Ochlockonee Bay (USA) (Nixon et al. 1996).

The input of total oxidised nitrogen (TOxN, which was $99 \% \mathrm{NO}_{3}{ }^{-}$) was equivalent to an areal sediment $\mathrm{N}$ load in the upper Great Ouse estuary of $455 \mathrm{~mol} \mathrm{~N} \mathrm{~m}^{-2} \mathrm{yr}^{-1}$ for 1993. Based on simple areal calculations there was only a very small attenuation $(\sim 1 \%)$ of this TOxN load by the sediments of the upper estuary (Nedwell \& Trimmer 1996). However, when the $50 \mathrm{~km}^{2}$ of sediment at the mouth of the estuary was also considered, the annual areal $\mathrm{N}$ load decreased from 455 to $20 \mathrm{~mol} \mathrm{~N} \mathrm{~m}^{-2} \mathrm{yr}^{-1}$. The total amount of denitrification for the entire estuary was calculated to be $4400 \mathrm{~mol} \mathrm{~N} \mathrm{~h}{ }^{-1}$ or $3.2 \mathrm{Mmol} \mathrm{N} \mathrm{mo}^{-1}$ or 38.4 $\mathrm{Mmol} \mathrm{N} \mathrm{yr}^{-1}$. The monthly denitrification rate was then compared to the monthly TOxN loads and the per- 
centage attenuation calculated (Fig, 9). Attenuation of the TOxN load ranged from $1 \%$ in the middle of winter to $56 \%$ at the height of summer, when pelagic primary production and $\mathrm{N}$ demand would have been maximal. Similar relationships were reported for the Tamar, UK (Law et al. 1991). Nixon et al. (1996) suggested that the percentage of an estuarine Total Nitrogen (TN) load denitrified was related to the log mean residence time (months) of an estuary. Using the relationship $y=20.8 \log (x)+22.4$, Nixon et al. (1996) predicted that 21 and $2 \%$ of TN load for the Great Ouse ( $99 \%$ TOxN) would be denitrified for residence times of $25 \mathrm{~d}(0.8 \mathrm{mo})$ and $3 \mathrm{~d}(0.1 \mathrm{mo})$ respectively. These values are at least comparable to our calculated values of 56 and $2 \%$ respectively.

As well as the direct removal by sediments of $\mathrm{NO}_{3}{ }^{-}$from the water column, sediments can be significant sources of fixed inorganic $N$ (Billen \& Lancelat 1988). Assigning the annual $\mathrm{NH}_{4}{ }^{+}$efflux values (Table 3 ) to each sector of the estuary suggests that the sediments recycle back to the water column $128 \mathrm{Mmol} \mathrm{N} \mathrm{yr}{ }^{-1}$ as $\mathrm{NH}_{4}{ }^{+}$, an amount equal to 9 times the annual riverine $\mathrm{NH}_{4}{ }^{+}$load flowing into the Great Ouse estuary. Using an estimate for net primary production in the Southern North Sea (North British Coastal Waters, ICES region 3) of $75 \mathrm{~g} \mathrm{C} \mathrm{m}^{-2} \mathrm{yr}^{-1}$ (Joint \& Pomroy 1993), the amount of $\mathrm{N}$ required to support a proportionate amount of primary production in the area of the Wash could be calculated $\left(595 \mathrm{Mmol} \mathrm{N}\right.$ yr $^{-1}$; assuming Redfield $\mathrm{C}: \mathrm{N}$ ratios of $7: 1$; Redfield et al. 1963). The calculated total efflux of $\mathrm{NH}_{4}{ }^{+}$from the sediments of the lower Great Ouse estuary $\left(50 \mathrm{~km}^{2}\right)$ could potentially provide $22 \%$ of the annual primary production $\mathrm{N}$ requirement in the Wash.

Acknowledgement. This work was part of the JoNuS (Joint Nutrient Study) programme funded by the Ministry of Agriculture, Fisheries and Food, the Department of the Environment and the Environment Agency (all UK). The views expressed are those of the authors and do not reflect the policies of the funding departments.

\section{LITERATURE CITED}

Abd Aziz SA, Nedwell DB (1988) The nitrogen cycle of an east coast, U.K. saltmarsh: ii. Nitrogen fixation, nitrification, denitrification, tidal exchange. Estuar Coast Shelf Sci 22: $689-704$

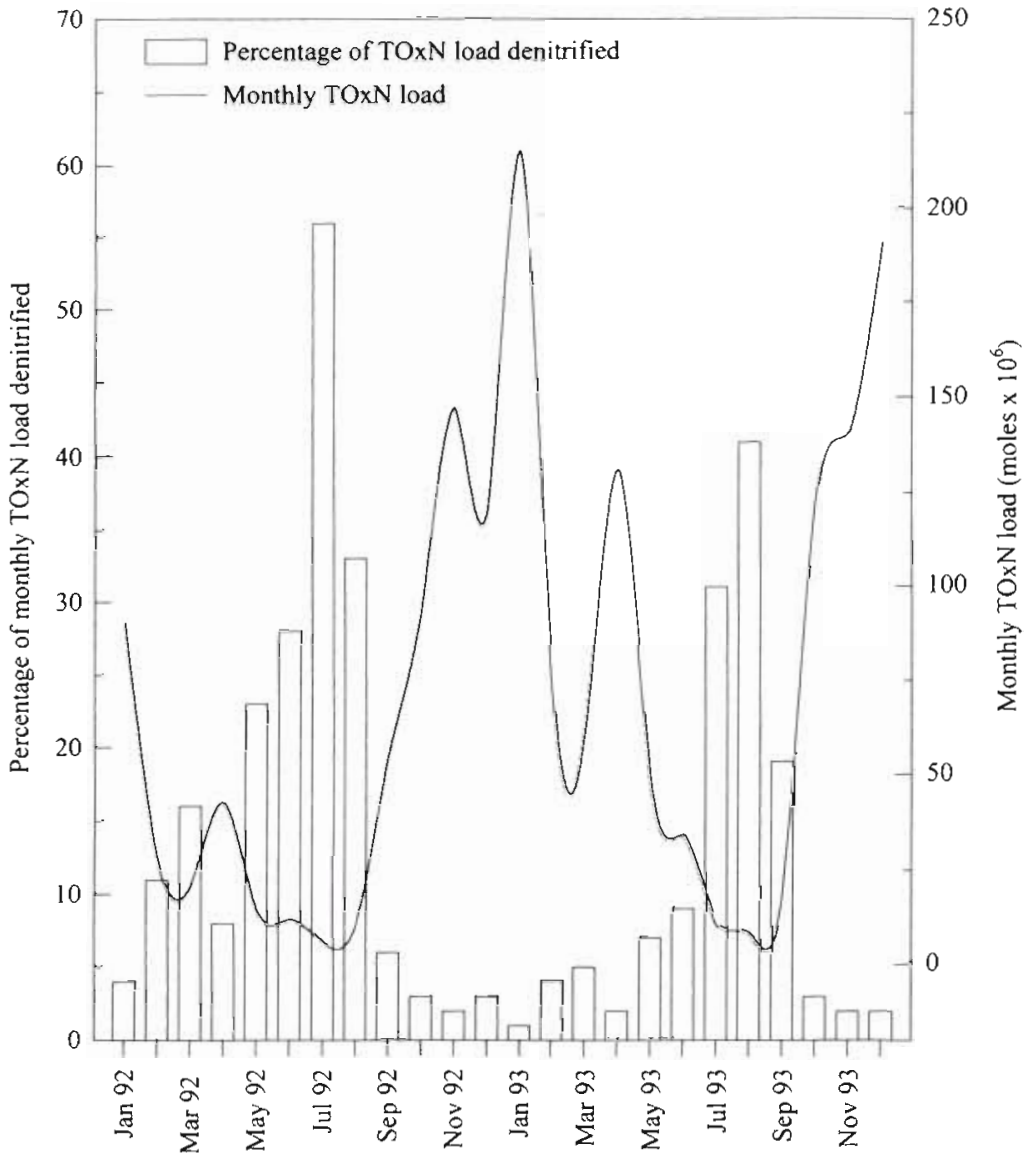

Fig. 9. Seasonality of the percentage of total oxidised nitrogen (TOxN) load denitrified and the monthly TOxN load for the Great Ouse estuary from January 1992 to December 1993

Andersen FO, Helder W (1987) Comparison of oxygen microelectrodes, oxygen flux rate and electron transport system activity in coastal marine sediments. Mar Ecol Prog Ser 37 : $259-264$

Balls PW (1994) Nutrient inputs to estuaries from nine Scottish east coast rivers; influence of estuarine processes on inputs to the North Sea. Estuar Coast Mar Sci 39:329-352

Billen G, Lancelot C (1988) Modelling benthic nitrogen cycling in temperate coastal ecosystems. In: Blackburn $\mathrm{TH}$, Sorensen $J$ (eds) Nitrogen cycling in coastal marine environments. SCOPE Report 33. Wiley, New York, p $341-378$

Billen G, Somville M, de Becker E, Servais P (1985) A nitrogen budget of the Scheldt hydrographical basin. Neth J Sea Res 19:223-230

Binnerup SJ, Jensen $\mathrm{K}$, Revsbech NP, Jensen MH, Sørensen J (1992) Denitrification, dissimilatory reduction of nitrate to ammonium, and nitrification in a bioturbated estuarine sediment as measured with ${ }^{15} \mathrm{~N}$ and micro sensor techniques. Appl Environ Microbiol 58:303-313

Blackburn TH, Henriksen K (1983) Nitrogen cycling in different types of sediments from Danish waters. Limnol Oceanogr 28:477-493

Blackburn TH, Lund BA, Krom MD (1988) C- and N- mineral- 
isation in the sediments of earthen marine fishponds. Mar Ecol Prog Ser 44:221-227

Boucher G, Boucher-Rodoni R (1988) In situ measurements of respiratory metabolism and nitrogen fluxes at the interface of oyster beds. Mar Ecol Prog Ser 44:229-238

Boucher G, Clavier J, Garrique C (1994) Oxygen and carbon dioxide fluxes at the water-sediment interface of a tropical lagoon. Mar Ecol Prog Ser 107:185-193

Cammen LM (1991) Annual bacterial production in relation to benthic microalgal production and sediment oxygen uptake in an intertidal sandflat and an intertidal mudflat. Mar Ecol Prog Ser 7 1:13-25

Davidson NC, Laffoley Dd'A, Doody JP, Way LS, Gordon J, Key R, Drake CM, Pienkowski MW, Mitchell RM, Duff KL (1991) Nature conservation and estuaries in Great Britain. Nature Conservancy Council, Peterborough

Enoksson V, Rüdén-Berg L (1983) A system for determining exchange between sediment and water exemplified by nitrogen flux under controlled oxygen conditions. Environ Biogeochem Ecol Bull 35:243-250

Enoksson V, Samuelsson MO (1987) Nitrification and dissimilatory ammonium production and their effects on nitrogen flux over the sediment-water interface in bioturbated coastal sediments. Mar Ecol Prog Ser 36:181-189

Forsgren G, Jansson M, Nilsson P (1996) Aggregation and sedimentation of iron, phosphorus and organic carbon in experimental mixtures of freshwater and estuarine water Estuar Coast Shelf Sci 43:259-268

Gardner WS, Seitzinger SP, Malczyk JM (1991) The effects of sea salts on the forms of nitrogen released from estuarine and freshwater sediments: does ion pairing affect ammonium flux? Estuaries 14:157-166

Gould DJ, Dyer MF, Tester DJ (1987) Environmental quality and ecology of the Great Ouse estuary. Wat Pollut Cont 86: $84-103$

Hansen LS, Blackburn TH (1991) Aerobic and anaerobic mineralisation of organic material in marine sediment microcosms. Mar Ecol Prog Ser 75:283-291

Hargrave BT, Philips GA (1981) Annual in situ carbon dioxide and oxygen flux across a subtidal marine sediment. Estuar Coast Shelf Sci 12:725-737

Hopkinson CS (1987) Nutrient regeneration in shallow-water sediments of the estuarine plume region of the nearshore Georgia Bight, U.S.A. Mar Biol 94:127-142

Hopkinson CS, Wetzel RL (1982) In situ measurements of nutrient and oxygen fluxes in a coastal marine benthic community. Mar Ecol Prog Ser 10:29-35

Howes BL, Dacey JWH, King GM (1984) Carbon flow through oxygen and sulphate reduction pathways in saltmarsh sediments. Limnol Oceanogr 29:1037-1051

Ingvorsen $\mathrm{K}$. Jørgensen $\mathrm{BB}$ (1982) Seasonal variations in $\mathrm{H}_{2} \mathrm{~S}$ emission to the atmosphere from intertidal sediments in Denmark. Atmos Environ 16:855-865

Joint IR, Pomroy AJ (1993) Phytoplankton biomass and production in the Southern North Sea. Mar Ecol Prog Ser 99: $169-182$

Jørgensen BB (1977) The sulphur cycle of a coastal marine sediment (Limfjorden, Denmark). Limnol Oceanogr 22: $814-832$

Jørgensen BB (1982) Mineralisation of organic matter in the sea bed-the role of sulphate reduction. Nature 296: $643-645$

Jørgensen BB, Sørensen J (1985) Seasonal cycles of $\mathrm{O}_{2}, \mathrm{NO}_{3}{ }^{-}$ and $\mathrm{SO}_{4}{ }^{2-}$ reduction in estuarine sediments: the significance of an $\mathrm{NO}_{3}{ }^{-}$reduction maximum in spring. Mar Ecol Prog Ser 24:65-74

Jørgensen KS (1989) Annual pattern of denitrification and ritrate ammonification in estuarine sediment. Appl Environ Microbiol 55:1841-1847

Jørgensen KS, Sørensen J (1988) Two annual maxima of ritrate reduction and denitrification in estuarine sediment (Norsminde fjord, Denmark). Mar Ecol Prog Ser 48: $147-154$

Kaplan WA, Teal JM, Valiela I (1977) Denitrification in saltmarsh sediments: evidence for seasonal temperature selection among populations of denitrifiers. Microb Ecol 3: 193-204

Kelly RJ, Nixon SW (1984) Experimental studies of the effect of organic deposition on the metabolism of a coastal marine bottom community. Mar Ecol Prog Ser 17:157-169

Kemp WM, Boynton WR (1984) Spatial and temporal coupling of nutrients inputs to estuarine primary production: the role of particulate transport and decomposition. Bull Mar Sci 35:522-535

King DH, Nedwell DB (1984) Changes in the nitrate-reducing community of an anaerobic saltmarsh sediment in response to seasonal selection by temperature. J Gen Microbiol 130:2935-2941

King DH, Nedwell DB (1985) The influence of nitrate concentration upon the end-products of nitrate dissimilation by bacteria in anaerobic saltmarsh sediment. FEMS Microbiol Ecol 31:23-28

Kirkwood DS (1992) Stability of solutions of nutrient salts during storage. Mar Chem 38:151-164

Kirkwood DS (1996) Nutrients: practical notes on their determination in seawater. Techniques in marine environmental science no. 17. ICES, Copenhagen

Koch MS, Maltby E, Oliver GA, Bakker SA (1992) Factors controlling denitrification rates of tidal mudflats and fringing saltmarshes in south-west England. Estuar Coast Shelf Sci 34:471-485

Koike I, Hattori A (1978) Denitrification and ammonia formation in anaerobic coastal sediments. Appl Environ Microbiol 35:278-282

Law CS, Rees AP, Owens NJP (1991) Temporal variability of denitrification in estuarine sediments. Estuar Coast Shelf Sci 33:37-56

Lomstein BAa, Blackburn TH, Henriksen K (1989) Aspects of nitrogen and carbon cycling in the northern Bering Shelf sediment. 1. The significance of urea turnover in the mineralisation of $\mathrm{NH}_{4}{ }^{+}$Mar Ecol Prog Ser 57:237-247

Mackin JE, Swider KT (1989) Organic matter decomposition pathways and oxygen consumption in coastal marine sediments. J Mar Res 47:681-716

Marnette ECL, Hordijk CA, van Breemen N, Cappenberg TE (1992) Sulphate reduction and S-oxidation in a moorland pool sediment. Biogeochemistry 17:123-143

Nedwell DB (1975) Inorganic nitrogen metabolism in a eutrophicated tropical mangrove estuary. Water Res 9 : $221-231$

Nedwell DB (1982) Exchange of nitrate, and the end products of bacterial nitrate reduction, between seawater and sediment from a U.K. saltmarsh. Estuar Coast Shelf Sci 14: $557-566$

Nedwell DB (1987) Distribution and pool sizes of microbially available carbon in sediment measured by a microbiological assay. FEMS Microbiol Ecol 45:47-52

Nedwell DB, Blackburn TH, Wiebe WJ (1994) Dynamic turnover of organic carbon, nitrogen and sulphur in the sediments of Jamaican mangrove forest. Mar Ecol Prog Ser 110:223-231

Nedwell DB, Trimmer $M(1996)$ Nitrogen fluxes through the upper estuary of the Great Ouse, England: the role of the bottom sediments. Mar Ecol Prog Ser 142:273-286 
Nedwell DB, Walker TR, Ellis-Evans JC, Clarke A (1993) Measurements of seasonal rates and annual budgets of organic carbon fluxes in an antarctic coastal environment at Signy Island, South Orkney Islands, suggest a broad balance between production and decomposition. Appl Environ Microbiol 59:3989-3995

Nielsen K, Nielsen LP, Rasmussen P (1995) Estuarine nitrogen retention independently estimated by the denitrification rate and mass balance methods: a study of Norsminde Fjord, Denmark. Mar Ecol Prog Ser 119:275-283

Nielsen LP (1992) Denitrification in sediment determined from nitrogen isotope pairing. FEMS Microbiol Ecol 86: $357-362$

Nixon SW, Ammerman JW, Atkinson LP, Berounsky VM, Billen G, Boicourt WC, Boynton WR, Church TM, DiToro DM, Elmgren R, Garber JH, Giblin AE, Jahnke RA, Owens NJP, Pilson MEQ, Seitzinger SP (1996) The fate of nitrogen and phosphorus at the land-sea margin of the North Atlantic Ocean. Biogeochemistry 35:141-180

Ogilvie B, Nedwell DB, Harrison RM, Robinson A, Sage A (1997) High nitrate, muddy estuaries as nitrogen sinks: the nitrogen budget of the River Colne estuary (United Kingdom). Mar Ecol Prog Ser 150:217-228

Redfield AC, Ketchum BH, Richards FA (1963) The influence of organisms on the composition of seawater. In: Hill MN (ed) The sea, Vol 2. Intersciences, London, p 26-77

Risgaard-Petersen N, Rysgaard S, Nielsen LP, Revsbech NP (1994) Diurnal variation of denitrification and nitrification in sediments colonised by benthic microphytes. Limnol Oceanogr 39:573-579

Rysgaard S, Christensen PB, Nielsen LP (1995) Seasonal variation in nitrification and denitrification in estuarine sedi-

Editorial responsibility: Otto Kinne (Editor),

Oldendorf/Luhe, Germany ment colonised by benthic microalgae and bioturbating infauna. Mar Ecol Prog Ser 126:111-121

Seitzinger S, Nixon S, Pilson MEQ, Burke S (1980) Denitrification and $\mathrm{N}_{2} \mathrm{O}$ production in near-shore marine sediments. Geochim Cosmochim Acta 44:1853-1860

Sloth NP, Blackburn TH, Hansen LS, Risgaard-Petersen N, Lomstein BAa (1995) Nitrogen cycling in sediments with different organic loading. Mar Ecol Prog Ser 116:163-170

Sørensen J, Jørgensen BB, Revsbech NP (1979) A comparison of oxygen, nitrate and sulphate respiration in coastal marine sediments. Microbial Ecol 5:105-115

Tait RV (1981) Elements of marine ecology, 3rd edn. Butterworths, London

Uncles RJ, Stephens JA (1993) Nature of the turbidity maximum in the Tamar estuary, U.K. Estuar Coast Shelf Sci 36 : 413-431

Upton AC, Nedwell DB, Parkes RJ, Harvey SM (1993) Seasonal benthic microbial activity in the southern North Sea; oxygen uptake and sulphate reduction. Mar Ecol Prog Ser 101:273-281

Van Es FB, Meyer-Reil LA (1982) Biomass and metabolic activity of heterotrophic marine bacteria. Adv Microb Ecol $6: 111-170$

Watson PG, Frickers PE, Howland RJM (1993) Benthic fluxes of nutrients and some trace metals in the Tamar estuary, $\mathrm{S}$. W. England. Neth J Aquat Ecol 24:135-146

Wellsbury P, Herbert RA, Parkes RJ (1996) Bacterial activity and production in near-surface estuarine and freshwater sedinents. FEMS Microbiol Ecol 19:203-214

Yoon WB, Benner R (1992) Denitrification and oxygen consumption in sediments of two south Texas estuaries. Mar Ecol Prog Ser 90:157-167

Submitted: September 5, 1997; Accepted: January 2, 1998 Proofs received from author(s): February 18, 1998 